\title{
MULTIPOLARITY AND STABILITY IN ASIA
}

\author{
by
}

Duong Nu Hoang Anh

\begin{abstract}
A Thesis
Submitted to the Victoria University of Wellington in Partial Fulfillment of the Requirements for the Degree of Master of International Relations (MIR)

School of History, Philosophy, Political Science and International Relations

Victoria University of Wellington
\end{abstract}

2013 


\title{
Multipolarity and Stability in Asia
}

\author{
by Dương Nữ Hoàng Anh
}

Completed in partial fulfilment of the Master of International Relations degree

School of History, Philosophy, Political Science and International Relations 


\begin{abstract}
This thesis considers the relationship between multipolarity and stability in Asia. Stability can be perceived as a system's tendency towards equilibrium and will be examined in terms of war avoidance of the great powers and the stability of the distribution of power in the region. In the next twenty or thirty years, Asia will be increasingly multipolar in the form of either three powers (the United States (US), China, and India) or four (the US, China, India and Japan). I argue that a more multipolar Asia will reduce the likelihood of great power wars because of increasing economic interdependence and the calculations by states of their national interests. However, in terms of the stability of the distribution of power, the new distribution of power will involve a balance between the US, China and India, but it still remains contested due to questions raised about China's and India's legitimacy. In general, while Asia is more likely to be stable in Asia if it is multipolar, the likelihood of conflicts between China and India remains an open question. I conclude that the stability in Asia depends not only on the structure of the system but also other factors such as these major states' uncontrolled actions and behaviors in response to other states in the system.
\end{abstract}




\section{ACKNOWLEDGEMENTS}

I have been really looking forward to writing the acknowledgement section since I began to search and work on the thesis. This thesis is not only a fruit that results from my efforts but also from the very kind help of other people.

First of all, I wish to express sincere appreciation to my supervisor, Professor Robert Ayson, who was highly dedicated and very generous in his assistance and guidance during the process of my research and writing. Sometimes, I felt disappointed and got stuck in the thesis but he encouraged me and made me more confident to continue my work.

Secondly, I would like to thank the Vietnamese Communist Party and Vietnamese government for releasing the 165 projects aimed at improving the quality of team leaders, and management of the political system to meet the requirements of the period of promoting industrialization / modernization of the country. Therefore, someone who is living in remote areas like me has better conditions in terms of time and money to improve their English and study science.

Thirdly, I wish to express thanks to QuangNam's Party Committee, the government and QuangNam radio/television station where I am working and living for creating advantages for my studying.

Fourthly, I thank my lecturers who come from Victoria University of Wellington, Diplomatic Academy of Vietnam, my colleagues and friends who shared the knowledge and experiences of life with me, and special 
thanks to James McKenna, who was a proofreader to my draft. I am grateful for all your patience and encouragement.

Finally, I would like to say a special thank to all members in my family, who have shared difficulties and happiness with me and helped me so much over the past years. As a result, I have had enough will and energy to overcome most difficult periods and finish my task. 


\section{TABLE OF CONTENTS}

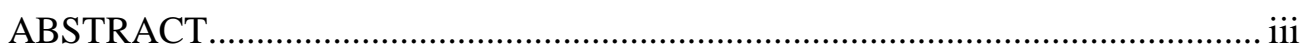

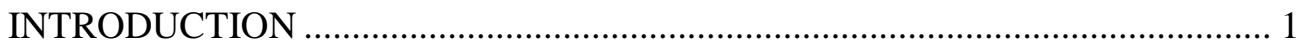

CHAPTER ONE: An overview of Multipolarity and Stability .............................. 7

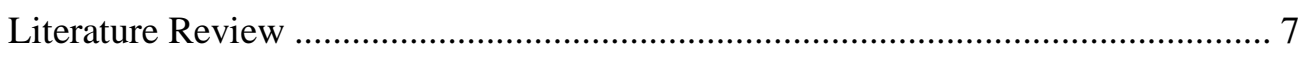

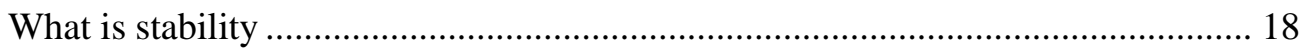

The Relationship between Multipolarity and Stability .......................................... 21

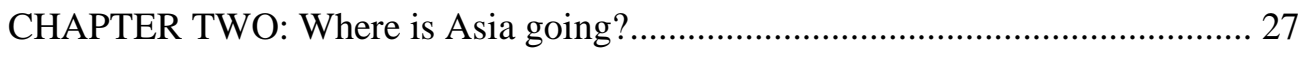

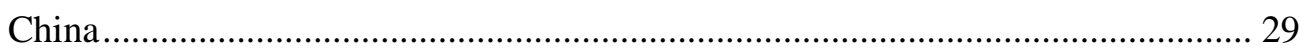

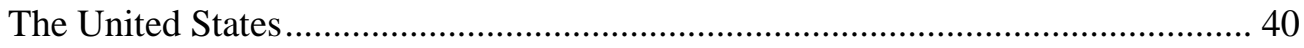

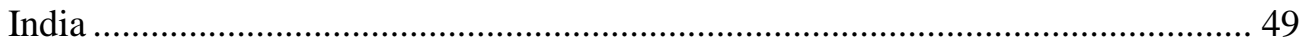

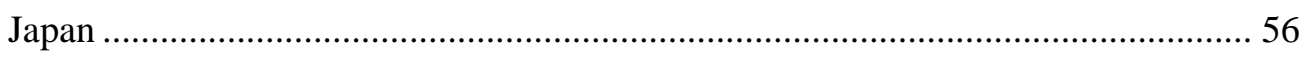

CHAPTER THREE: Multipolarity and Stability in Asia ....................................... 66

The Likelihood of war avoidance by the great powers ......................................... 68

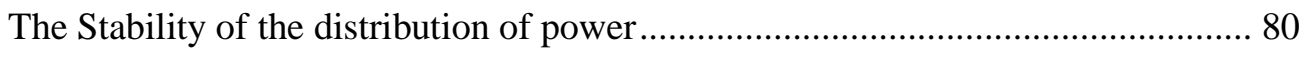

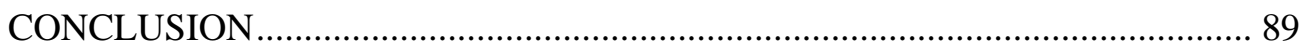

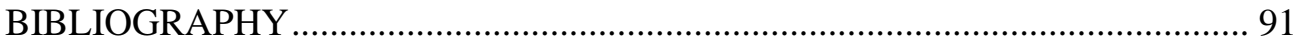

vi 


\section{INTRODUCTION}

There is a current debate among international relations academics and circles about whether the contemporary world system is becoming bipolar or multipolar, and which system is more stable or less stable in the wake of the Cold War (Christensen and Jack Snyder, 1990; Walt, 2011; Scowcroft, 2012). This is because, according to realists, the structure of the world system (unipolarity, bipolarity and multipolarity) impacts on the stability of its order (Mearsheimer, Summer 1990; Waltz, 1964). In contrast to realists, liberals are more optimistic about the prospects for peace in the world, especially in terms of Asia, which is appreciated as a distinct area of increasing prosperity due to increasing economic interdependence, the spread of democracy, and the growth of international institutions. However, in the eyes of other scholars, despite enjoying "the most peaceful era" over the past decades (Human Security Report 2009/2010: p.45), the Asia-Pacific region also remains "one of the leading arenas for great power competition and at the same time contains the potential for serious internal conflict and disorder" (Ayson, 2005, p. 190). Therefore, this region raises ongoing debates by Western as well as Eastern scholars about the reasons why Asia has obtained peacefulness over the past decades and whether this will continue. The core of these debates relates to whether contemporary Asia is becoming (or is already) a multipolar system, and whether such a shift will result in a more or less stable system. This paper seeks to examine this debate and provide an answer. However in contrast to some of the other researchers, it will start by defining the term stability in a wider sense than 
the common assumption made in much of the literature; that stability simply means the unlikelihood of war.

As will be shown, a system can be said to be stable when it has a tendency towards equilibrium and especially in its ability to return or reach a new equilibrium. In fact, defining stability in certain perspectives will bring different assessments of Asia's stability or instability in the context of Asian multipolartiy due to the characteristics and reciporocal interaction between these two variables. If we consider stability as the likelihood of peace and war, inevitably we will have different assessments of the situation than if we define stability as being related to equilibrium and the avoidance of harm.

The next part of the dissertation will examine the characteristics of multipolarity that influence the stability of international and regional systems. It will also investigate the relationship between multipolarity and the stability that help us to have objective and unbiased assessments about developments in the Asian region as well as the impact of multipolarity on Asia's stability. Then we should be able to examine whether Asia is moving toward multipolarity or not.

The remaining part of this study is devoted to an assessment of stability in the context of Asian multipolarity as it applies to a series of real-world issues involving the major powers in Asia, including war avoidance by the great powers and the stability of the distribution of power. From here, it will consider whether multipolarity leads or does not lead to regional stability and particularly which elements contribute to Asia's stability outside of the structure of the system that realists always focus on. Analysis in this paper will confirm that Asia's stability depends not only on the structure of the system but also on other factors such as economic interdependence, and the 
understanding of leaders regarding war and peace in the contemporary world and their abilities to control states' fears as they face a security dilemma. In general, wars are hard to predict and Asia's future will remain a mix of cooperation and competition between the great powers. While it might be unlikely for major wars to occur, in the short term there will be hotspots over territorial disputes and nuclear crises in Asia.

Finally, the concluding section suggests policy implications that follow from my analysis. Nevertheless I should note in advance that in this paper I will not discuss which pattern is more stable or less stable among unipolar, bipolar and multipolar systems. Instead of doing so, I will clarify which model Asia might head toward and how this will effect regional stability. Will it be more stable or less stable than the past or current system? Accordingly, I argue that Asia will be more multipolar with the dominance of three major powers including the US, China and India, or of four major powers including the US, China, India and Japan; if Japan can overcome its current challenges. However, while considering this issue, I find out that it is more likely to envisage that Asia will be dominated by three leading powers including China, the US and India, instead of four leading powers including Japan. Therefore, while assessing the consequences of multipolarty towards the stablity of the region in chapter three, I will only take into consideration the dominance of the US, China and India in Asian multipolarity due to this model's greater likelihood.

\section{Why is the topic important?}

According to international relations scholars in general, Asia is heading toward multipolarity (or is already there). It is believed that Asia's 
continuing prosperity and security depends upon the stability of the region. However some argue that if Asia becomes more multipolar it will become less stable. Therefore our analysis of whether Asia is heading towards multipolarity or not and the impact of any such change on the stability of system will be an important contribution to international relations research as well as policy-making in states. For academics, identifying Asia's future changes and their effects on international system will contribute new thinking or perspectives under new and different circumstances to international relations theories. This is also a concern of some scholars. For example, Kang (2003) suggests a new framework of international relations in the context of changing Asia:

"Efforts to explain Asian issues using international relations theories largely derived inductively from the European experience can be problematic" (Kang, 2003, p.59). Furthermore, Kang also pointed out that:

"The paradigm wars have grown stale: Pitting realism, constructivism, and liberalism against one another and then attempting to prove one right while dismissing the others has created a body of soul-crushingly boring research. More useful approaches would include moving within the paradigms and examining the interaction between the unit level and the system. In this vein, recognition that Northeast, Southeast and South Asia may offer new insights to international relations theorists should be welcome. Examining the possibility that these regions may pose new empirical and theoretical challenges could lead to a fruitful research agenda. Moving the field of international relations in this direction however will not be easy" (Kang, 2003, p.83).

In addition, another scholar raises the view that:

“either general approach to explaining international relations, realism or liberalism, leaves open many possible predictions in Asia. Only more specific theories within these broad schools offer clear predictions, which mean that there is not yet any wide analytical consensus to serve as a basis for prescription" (Betts, 1993-1994, p. 74). 
These suggestions as well as the ongoing debate among international relations academics show an expectation of the need for a deeper insight into Asian security in the context of Asia's rapidly economic and social development and international and regional security interactions.

In terms of policy-makers who establish a state's foreign and national policies, an accurate view about Asia's future will help them set up and implement more suitable policies contributing to maintaining peace and stability in the region and each state itself, and is indispensable for Asia's continuing prosperity and security. In other words, the actions and responses of states in the region have an impact on the others. Therefore, it is important to correctly perceive the situations happening in the region associated with the multpolar model. For example, does multipolarity really help us understand South China Sea issues due to the intertwined interactions between several actors inside and outside of the region or does the multipolar system help to avoid the great power's wars or favour instability? The most important thing is that in the context of Asian multipolarity, how do state leaders perceive the interactions between states and how should states develop foreign policies to ensure their national interests in regional peace. For example, New Zealand's Ministry of Foreign Affairs and Trade has noted:

"There are a number of trouble spots in the region, any of which could flare up and destabilise the regional and in some cases the global security situation. The obvious areas of risk are the Korean Peninsula, Taiwan/China, the South China Sea and South Asia. Conflict in any of these areas would affect important New Zealand interests" (New Zealand's Foreign and Security Policy Challenges, June 2000).

Likewise, Australia has shown in a recent study of the government that “Australia's future prosperity and security are inextricably linked to what 
happens in our region.... What the countries of the region, including Australia, do to shape the future, through effective statecraft and domestic policy reform will be critical” (Australian in the Asian Century, 2012). Or as Hillary Clinton said when she was the US Secretary of State- : “Asia's remarkable economic growth over the past decade and its potential for continued growth in the future depend on the security and stability that has long been guaranteed by the US military" (Clinton, 2011, p. 62). These concerns and hopes show that we should try to perceive where Asia is going; whether it will be stable or unstable; and how to make it more stable. For instance, if multipolarity results in instability in international system as realists argue, Chinese foreign policymakers should avoid implementing policies that might make more mistrust and misunderstanding to other states. As for India, this state should prevent China's aggression by undertaking counter-containment to ensure Indian and regional continuous prosperity and peacefulness. Or in case of the stability, the US should contain China's growth by its presence in Asia to avoid Chinese hegemony and to ensure the US leading role and its economic interests. So it is hoped that this thesis will contribute perspectives about Asia's future to international academics and political leaders to apply to great powers and small powers in the region. 


\section{CHAPTER ONE: AN OVERVIEW OF MULTIPOLARITY AND STABILITY IN ASIA}

\section{Literature review}

\section{Asia's future will be unstable}

Polarity in international relations is a description of the distribution of power within the international system. For example, bipolarity is a distribution of power in which two great powers have nearly equal influence on the international system. Multipolarity involves more than two great powers which have considerable amounts of military, cultural, and economic influence (N.D.Arora, 2010). In international relations debates, some argue that Asia is heading toward bipolarity with the dominance of the United States and China (Ross, 1999), unipolarity with the US as hegemon (in spite of emerging states) (Berger, July 2000) or a hierarchical order with the Chinese dominant and a periphery including surrounding states (Kang, 2003; Kupchan, Autumn, 1998). But most scholars affirm that Asia is heading towards multipolarity (Friedberg A. L., Winter, 1993-1994; Betts, Winter, 1993-1994; Berger, July 2000; Thomas J.Christense; Jack Snyder, 1990). According to several scholars (Friedberg A. L., Winter, 1993-1994; Betts, Winter, 1993-1994; Kupchan, Autumn, 1998; Segal, Summer, 1993), if Asia becomes more multipolar it will become less stable. 
The most influential argument among international relations academics and political circles is expressed in the article entitled "Ripe for Rivalry" written by Aaron Friedberg (Friedberg, Winter, 1993-1994) and some of his other articles (Friedberg, 2000a and Friedberg, 2000b). Under Friedberg's logic, Asia is heading toward multipolarity in the context of the continuing US presence and China's rise as well as other major states emerging in the region such as Russia and Japan. The new distribution of power makes the region unstable due to great power competition and imbalances in other factors between states such as economic development, political regimes and the spread of nuclear weapons (Friedberg, Winter, 1993-1994). If the US withdraws from the region, states might bandwagon with China and the region might be peaceful. However, if the US remains present, there will be conflict between these two great powers according to Friedberg. The US will be able to accept to some extent China's ambitions but will not withdraw from the region to abandon its earlier predominance while China will always want to be dominant in Asia. The balance of power at that time will be fragile as China will think that the US is trying to contain her in the region (Friedberg, 2000a, p. 156-157). As a result, the relationship between the two great powers contains cooperative and competitive elements and they consider each other as potential military rivals. The outcome of this rivalry will be "the struggle for mastery" in Asia. Actually, in my opinion, Friedberg's approach expresses his weakness in assessing the multipolar model in Asia. The reason being, that if the relations of states are only focused on these two great powers, that will be a bipolar system, not multipolar one as he assumes. Therefore, this weakness will be discussed clearly in the third chapter of this thesis. 
Apart from the relationship between these two great powers, interactions in a multipolar Asia impact on other great powers such as Japan, Russia or middle powers such as Taiwan and North Korea. Gerald Segal and Richard K. Betts foresee prospects of peace and war from a confrontation between the US and China; and between Japan and China in a multipolar Asia. Segal predicts "the coming confrontation between China and Japan" (1993) due to historical resentment and the desires to become a more normal great power on the part of the Japanese nationalists and young generations and in the context of China's increasing pursuit of nationalist aims that have been manifested by claims of territorial disputes and other activities as well. What is more, China always believes that China must have a dominant, not subordinate role to any states, especially to Japan in East Asia (Segal, 1993, p.28). So, the ambivalence between two great powers might lead to confrontation in the future.

In a similar fashion to Gerald Segal, Richard K. Betts argues that multipolarity is the most likely pattern to occur in East Asia with the likely dominance of great powers including Japan, China and Russia and an extraregional power like the United States. However, East Asia could be unstable rather than peaceful due to the flexible alignment of players and China is the state most likely over time to disturb the equilibrium in the region and the world according to Betts. From the liberal view, if China becomes more democratic, it would be good for it and for every one as well. Ironically, Chinese leaders perceive liberal ideology as a direct security threat to their regime. According to realist views, the answer for the question "Should we want China to get rich or not" will be no, because a rich China would overturn any balance of power (Betts, Winter, 1993-1994, p. 53-54). Therefore, Betts concludes that China's economic rise would cause conflicts 
with the United States and other Asian states, especially with Japan; in case the United States and Russia withdraw from the region (some would say Russia did so in the 1990s but that the US did not). In addition, if Japan becomes a normally armed state, it would be the strongest military power in Asia and its political frictions with other Asian countries, especially China, would increase as the past has shown (all three of Japan's wars in the past originated in disputes related to China). And in reality, there is not any reason to prevent Japan's rearmament. So, Betts asserts that stability in Asia in the past depended on the absence of strategic competition between these two great powers and that competition will increase in the future in the context of the China's rise and Japan's rearmament.

Perceiving that Asia's geopolitical future is unstable, Kupchan envisages chaos with an arms race between Southeast Asian countries after US hegemony disappears and the system returns to multipolarity. The transformation could trigger conflicts that can override other sources of peace (Kupchan, Autumn, 1998, p. 42). According to Kupchan, Asian peace over time has depended heavily on the US presence, but US dominance in Asia will not last.

In sum, scholars predict a multipolar Asia will be unstable with prospects of Japanese rearmament (Segal, Summer, 1993); China's revisionism; conflict or war over the status of Taiwan (Hughes, 1997); terrorist or missile attacks from a rogue North Korea against South Korea, Japan, or even the United States (Betts, Winter, 1993-1994, p. 66); and arms racing or even conflict in Southeast Asia, promoted in part by unresolved territorial disputes (Kupchan, Autumn, 1998, p. 44-45). These predictions are based on the following factors: an imbalance of power, wide disparities of economic 
development (Friedberg, 1993-1994; Kupchan, 1998; Betts, 1993-1994), the lack of international and regional institutions (Friedberg, 1993-1994; Kupchan, 1998; Betts, 1993-1994); different regimes and culturalideological variables (Friedberg, 1993-1994; Betts, 1993-1994); historical animosities and increasing nationalism (Friedberg, Winter, 1993-1994; Segal, Summer, 1993) and security dilemmas associated with nuclear weapons (Friedberg, Winter, 1993-1994).

\section{Asia's future will be stable}

Some who think Asia is heading towards stability argue that the rise of a revisionist China along with the declining hegemony of the US leaves a new balance of power in the Asian region and results in stability (Alagappa, December 2011; Berger, July 2000; Goh, Winter 2007-2008; Acharya, 2012; Kang, 2003; White, 2012; Choi, 2010-11-11). The reason for the stability and peace mainly comes from economic interdependence (Acharya, 2012; Alagappa, December 2011; Berger, July 2000; Kang, 2003; Goh, Winter 2007-200; Choi, 2010-11-1), the spread of democracy (Alagappa, December 2011), security requirements, and the deterrence created by nuclear weapons (Alagappa, December 2011; Choi, 2010-11-11). Berger indicates that Asian States' "intra-regional interdependence....has pushed up considerably the costs of military conflict', making such conflict less likely" (Berger, July 2000, p. 417). Alagappa predicts that: "Some conflicts will persist. Asia may face new security challenges. Military modernization will continue apace. Force will continue to be relevant in international politics and there will be military clashes. However, these clashes are unlikely to escalate into largescale war....China's rise can not necessarily have implications of inter-state war" (Alagappa, December 2011, p. 165 \&175). Alagappa argues that 
regional cooperation is a key driver for peace and stability over the next few decades as the distribution of power will change gradually; economic interdependence and the costs of using force make wars highly unlikely except for the pursuit of limited goals for all states in Asia, even China. Contrary to Friedberg and other scholars, Alagappa emphasizes the role and norms of regional institutions:

"the Asian normative structure enshrines principles and values such as mutual respect for the independence, sovereignty, quality, territorial integrity and national identity of all nations; the right of every state to lead its national existence free from external interference, subversion or coercion; the non interference in the domestic affairs of others; the settlement of differences or disputes by peaceful means; the renunciation of the threat or use of force; and effective cooperation action among parties to enhance national well-being" (Alagappa, December 2011, p. 179).

In a similar fashion to Alagappa, Acharya claims that while great power competition will not disappear, $21^{\text {st }}$ century Asia can avoid conflicts like Europe in the early $20^{\text {th }}$ century due to a combination of three factors including economic interdependence, US-centred alliances and cooperative institutions (Acharya, 2012).

While Friedberg is worried that the presence of nuclear weapons might lead to instability in Asia, optimists (Alagappa, December 2011; Choi, 2010-1111) argue that nuclear deterrence is a catalyst for reducing conflicts in the region. Alagappa has argued that: "in an age of nuclear weapons it is hardly likely that the US, China or other powers will seek to resolve their differences through the use of force...Uncertainty over the outcome of war further increases the cost of the force option, making it highly unlikely except for limited goals...The slow spread of nuclear weapons in Asia has had a stabilizing effect” (Alagappa, December 2011, pp. 174-175). And Choi 
has affirmed that "nuclear deterrence and economic interdependence among great powers will reinforce the stability in Asia. Thus I argue that although the system will be changed to a more complex multipolarity, the stable balance of power will restrain great powers in Asia while greatly reducing the possibility of miscalculations as a main source of conflict".

In an article published in 2003 entitled "Getting Asia wrong: the need for new analytical frameworks", David C. Kang rejects Friedberg's predictions that "Europe's past is Asia's future" because since the Cold War ended what the realists predicted has not come true and they have no evidence to confirm their advice to "just wait" (Kang, 2003, p. 61-63). Besides affirming like other scholars that increasing economic interdependence raises the cost of wars and forces China and other states to hesitate before going to war, Kang also believes in historical evidence that Asia was stable when China was strong and unstable when China was weak. In contrast to Friedberg and Segal's view, from the view of supporting the hierarchical order in Asia, Kang argues that, other states in the region, even Japan, can accept China's role as they did they in the past in the context of China's efforts seeking a compatible solution to engage in international and regional community and trying to stabilize the region. Therefore, Kang finds that balancing is not occurring against China because "there is likely to be far more stability in Asia and more bandwagoning with China" (Kang, 2003, p. 82) and "East Asia regional relations have historically been hierarchic, more peaceful, and more stable than those in the West" (Kang, 2003, p. 66).

\section{Uncertainty of Asia's future}

When considering the application of broader ideas to the Asian context, Thomas Berger assumes that there is no evidence that conflicts in Asia are 
inevitable (Berger, July 2000). Despite the multipolar trend as Friedberg argues, Berger asserts that the distribution of power is still a unipolar one because there is no country comes close to the US in strategic or conventional military capabilities since the end of the Cold War. As a result, in contrast to Aaron Friedberg and other realists, Berger shows that recent developments such as the balance of power, economic interdependence, and the growth in international institutions, geostrategic and geo-economic structural forces support greater regional stability whereas other factors including China's rise and culture-ideology contribute to a potentially dangerous and unstable Asia. Utilizing both realist and liberal views, Berger argues that the North Korean and Taiwanese crises may be resolved; and the United States and Japan's relationship might grow and evolve. Nevertheless, from a Constructivist point of view, he argues that keeping a peaceful environment in Asia depends on "the intentions and perceptions of the actors in the system" that are easily changeable by the understanding of states rather than by the balance of power and economic interdependence as realists and liberals contend, and so may lead to an unstable Asia (Berger, July 2000, p. 406).

\section{Asia's continuing prosperity depends on its peace and stability}

Apart from predictions of Asia's instability or stability in the context of emerging multipolarity, the second significant aspect which arises from this literature review is that many think that Asia's continuing prosperity, security and confidence depend upon a stable region. For example, in assessing US strategic choices in Asia, Hugh White affirms that Asia's continuing prosperity depends on its peace and stability and as a result, the 
United States' economic interests also depends on this stability. So, the US will have three options including "withdrawal, competition and power share" with regard to China (White, 2012). Due to US economic interests in the region, White argues that the US should take the third option. First of all, Asia will continue to be a market for the US due to the region's dynamic development and America's access to its markets. If the US withdraws from the region, Asia will be in chaos because of regional great power competition, and this will impact on the region's and the US economy. In the case of competition between the US and China, the US would pay a high cost for the economic disruption and major military conflicts. Finally, the US can neither withdraw nor compete against China. This means that the US should choose the power-sharing option and play a role as an extra-balancer in a more multipolar Asia to keep Asia's continuing peace and stability. Given the extra-balancing role of the US, the region will be reassured by the balance of power between the US and China; and China and other great powers in the region. Therefore Asia will continue its prosperity and development and the US will benefit from this stability. Hence, under Hugh White's logic, Asia will become more multipolar but it will not be stable if it lacks the presence of the US. The multipolar system here will be either stable or unstable depending on the role of the US.

Not only scholars but also governments express their support for the idea that regional stability contributes to regional and national prosperity and security in Asia. This argument appears regularly in official publications and statements. In the National Security Strategy of the United States from 2002 to now, governments under different administrations such as George Bush and Barack Obama continuously refer to America's "strategy to promote a 
stable, peaceful, and prosperous Asia-Pacific region" (National Security Strategy of the United States, September 2002, p. 30).

Asia's dramatic economic growth has increased its connection to America's future prosperity, and its emerging centers of influence make it increasingly important. We have taken substantial steps to deepen our engagement in the region, through regional organizations, new dialogues, and high-level diplomacy. The United States has deep and enduring ties with the countries of the region, including trade and investment that drive growth and prosperity on both sides of the Pacific, and enhancing these ties is critical to our efforts to advance balanced and sustainable growth and to doubling U.S. exports (National Security Strategy of the United States, 2010, p. 43)”.

For its part, China, also has committed itself to "make unswerving efforts to safeguard and promote the peace, stability, prosperity and development of the Asia-pacific region in particular" (China's National Defense in 2000, 2000). China's Peaceful Development Road published by The State Council Information Office in 2010 argued that a peaceful international environment is a good condition for China's development and prosperity: "China's development is an important component of global development. China has promoted world peace with its own development and made contributions to the progress of mankind." (White Paper on Peaceful Development Road Published, 2010). As well as its interests in world peace, China also emphasizes her contribution to regional stability by her efforts engaging in international and regional economies and other issues. Also in relation to regional stability and security, Australia considers Asia as the world's most dynamic economic region and affirms that "Australia's future is irrevocably tied to the stability and sustainable security of our diverse region" (Australia in the Asian Century, October 2012, p. 3). While recognizing challenges Asia's future brings to this country, the Australian government foresees its 
opportunities and benefits from the region's development in the broad knowledge that the order of the region will be challenged by Asia's large powers such as China and India but regional security and prosperity depending on how major-power relations evolve, particularly between China, India, Japan and the United States. Therefore, regional security should be sustainable and all states including Australia should take responsibilities for a region of sustainable security to remain the regional stability and prosperity (Australia in the Asian Century, October 2012).

\section{Conclusion}

From the above arguments, we can see that many countries believe that Asia's continuing prosperity depends on its peace and stability and that their own prosperity also depends upon regional stability. Therefore, the debate over whether Asia is becoming more multipolar is important as the interactions between major states as well as middle and small states in the region depend on the numbers of great powers and relations between them. The more states in the system there are, the more complicated interactions between states become. It is difficult for states to calculate or to respond to the relations with other states. Some states might ally with other states against a potential hegemon for example. In this case, it is argued that whether Asia becomes less stable. Therefore, the first task of this paper is to show whether Asia is moving towards multipolarity or not, and the second is to consider the debate as to whether a more multipolar Asia will be more or less stable.

In addition, regional stability has clearly become an important issue and a concern of great powers in the world and in the region in particular. Hence, 
we should find out which factors make stability important in the context of Asian multipolarity. Are there several ways of defining the term stability? Muthiah Alagappa has rightly noted: "Stability, like peace, is a desirable goal, but countries differ on what constitutes stability" (quoted in Ayson, 2005, p.191). In order to answer these questions, this paper should next explore what stability is and consider the relationship between multipolarity and stability because we will different outcomes from different perspectives.

\section{What is stability?}

According to Oxford Advanced Learner's dictionary, the term stability means "the quality or state of being steady and not changing or being disturbed in any way (the quality of being stable)" (Oxford Advanced Learner's dictionary, 2013, http://oald8.oxfordlearnersdictionaries.com/). In international relations, stability may be considered from the vantage point of both the total system and the individual states comprising it (Deutsch, Singer, 1964). Accordingly, Karl Deutsch and Singer David J. assert that at the system level, stability equates to the survival of most of its members and the preventon of a single state from becoming dominant. At a subsystem level, stability is related to the probability of states' continued political independence and territorial intergrity without any significant probability of becoming engaged in a "war for survival" (Deutsch \& Singer, 1964, pp. 390391). Under this logic, stability refers to the unlikelihood of conflicts and if any state finds itself in a war for survival this will be considered an unstable situation. Nonetheless, if we see stability in this way it may be problematic due to its insufficiency. In theory as well as in reality it is completely obvious that an international system might transfer from an old model into a new pattern that is more stable than the earlier one. Of course, in that 
process, conflict and war is likely to occur. For example, after World War II, the world dominated by two great powers (the US and the Soviet Union) was more stable than earlier periods when the world was multipolar. (Perhaps stability is a measure here of the avoidance of great power war). Or in another example, as we can see, after the collapse of the Soviet Union in 1991, the world and especially Asia, have enjoyed a peaceful period under the unipolar moment of the US hegemon. Thus, we can believe in a fact that this transition of power did not bring instability for the system compared to earlier periods' stability.

In terms of individual states, we also cannot percieve Deutsch \& Singer' view mechanically that if wars that can threaten the survival of one or more states occur in any region, that region might also be considered unstable. In my opinion, stability in this way is understood in too narrow a sense. Instead of thinking in this way, I agree with the stability concept used by L.F.Richardson. By his definition, stability refers to any set of conditions under which the system would return to its equilibrium state. If any affair that would not so return, and rather would continue to change until reaching some limit or breakdown point of the system it will be unstable (quoted in Deutsch Karl W. and Singer David J., 1964, p. 391). Similarly, Robert Ayson also defined stability as including two factors: equilibrium and avoidance of major harm to a system (Ayson, 2005). Firstly, a stable system to him must obtain and maintain equilibrium. The stability requires the ability to cope with external shocks and changes to again reach the equilibrium. Therefore, we should keep in mind that we should not encourage the perception that stability is synomous with the status-quo, which is reflected also in the emphasis on persistence because of a fact that 
the initial establishment may be not in equilibrium and, so the status quo may be instability.

The second factor that should be perceived is that a system is considered as stable if it is able to avoid major harm at both system and individual state levels. There are two issues that need to be clear here. First of all, this should not be understood as meaning that war is impossible in the stable system because "a very damaging war might be considered a stable equilibrium in some situations, as might have been seen on the western front in the World War for example" (Ayson, 2005, p. 192). Secondly, the "avoidance of harm" does not only relate to the avoidance of conflict or war. Instead, it might involve the avoidance of economic disruption of states in the region; ie economic instability. It is because, as the equilibrium are unobtainable or lost, the costs are perceived to be able much higher (Ayson, 2005, p. 192). For this reason, elements of stability can be also understood as "the durability of a particular equilibrium" that might imply (1) the balance of power of two or more states or a particular system of government, for example; and (2) especially moving to "a new equilibrium". In other words, the first factor just refers to "preservation" but the second emphasizes a truly stable system that has abilities to identify, then provide for a stable pattern of behavior and replace the old pattern creating instability for some reasons. So, stability can be defined as "the ability of a given system of interstate relations to remain peaceful, including its ability to tolerate crises in a way which does not increase the likelihood of future armed conflict" (Ayson, 2005, p. 195).

In sum, stability can be viewed as a system's tendency towards equilibrium, including its ability to find a new equilibrium in changing conditions. Going 
even further, Robert Ayson concludes that the existence and durability of cooperation in many forms between states in the system reflect stability in interstate relations. An unstable system results from situations where there is poor cooperation and where conflict is prevalent (Ayson, 2005, p. 193). Thus, we should next examine the relationship between stability and multipolarity. How does multipolarity impact on regional stability? Might multipolarity completely determine regional stability?

\section{The Relationship between multipolarity and stability}

\section{Disadvantages of a multipolar system compared to a bipolar one}

From the viewpoint of neo-realists, the keys to war and peace lie more in the structure of the international system (ie a unipolar, bipolar or multipolar system) than in the nature of individual states. Mearsheimer points out that "Conflict is common among states because the international system creates powerful incentives for aggression. The root cause of the problem is the anarchic nature of the international system. In anarchy there is no higher body or sovereign that protects states from one another. Hence, each state living under anarchy faces the ever-present possibility that another state will use force to harm or conquer it. Offensive military action is always a threat to all states in the system" (Mearsheimer, Summer 1990, p.12). Waltz argues that stability can be "measured by the peacefulness of adjustment within the international system and by the durability of the system itself" (Waltz, Summer 1964). Or in other words, "no consequential variation takes place in the number of principal parties that constitute the system" (Waltz K., 1979). 
Under these assumptions, Mearsheimer and Waltz affirm that the bipolar world is in fact the most stable and durable for peace in the international system whereas the multipolar system creates more chances for conflict. For instance, envisaging Europe's future in the post- Cold war and its stability, Mearsheimer argued: "the bipolar structure that has characterized Europe since the end of World War II is replaced by a multipolar structure...The prospects for major crises and war in Europe are likely to increase markedly if the Cold War ends and this scenario unfolds" (Mearsheimer, Summer 1990, p. 7). In order to prove the bipolar system to be more stable than the multipolar one, Mearsheimer assumes the most important factor is the way that military power contributes to peacefulness or war in the past and even in the future of Europe. "The peacefulness of the postwar era arose for three principal reasons: the bipolarity of the distribution of power on the Continent, the rough equality in military power between those two polar states, and the apprearance of nuclear weapons, which vastly expanded the violence of war, making deterrence far more robust" (Mearsheimer, Summer 1990, p. 11). In contrast to this, wars before 1945 all originated from the imbalances of power that often occurred among states in the multipolar system.

Compared to bipolarity, multipolarity creates more opportunities for the great powers to fight each other since the more great powers there are, the more potential conflict dyads there are. This consideration could be explained by the fact that with more actors in the system, national interests are more complex and accommodation becomes more difficult. Therefore, the increase in the number of dyads inevitably leads to increases in conflicts of interests (Rosecrance, 1966, p. 329). This is also addressed by Karl Deutsch and Singer David J., who discuss the relationship between the 
number of actors and the stability of the system (Deutsch Karl W. and David Singer J., 1964). In addition, a large number of actors can lead to "buckpassing" (Mearsheimer, Summer 1990, p. 16) which is commonplace in the multipolar system, and balancing or bandwagoning behaviors (Walt, 1985) between a small power with a stronger power, making it difficult to cooperate and to offer deterrence due to a fear of being exploited, or each other's suspicion.

The second argument is the security dilemma which comes from the widespread distribution of nuclear weapons that contributes to destabilizing the multipolar system. As Aaron Friedberg showed in the context of Asia, some states, such as North Korea, are pursuing the acquisition of nuclear weapons, a process which could lead to nuclear escalation in the region. For example, efforts to manufacture nuclear weapons in North Korea might make Japan consider the possession of nuclear weapons. As a result, a similar development of nuclear weapons by Japan might cause China to expand and accelerate its nuclear program and hence, other states or areas such as Taiwan, India, Japan and Korea would shift their foreign policies in the context of nuclear escalation in Asia (Friedberg, Winter, 1993-1994, p. 27).

Finally, the multi-polar world would allow more opportunities for miscalculations and misperceptions between the many alliances and groupings due to more numerous dyads which encourage shifting coalitions and make greater instability (Waltz, 1979; Rosecrance, 1966; Mearsheimer, Summer 1990). Local wars can also occur under multipolarity so there always is a chance for a small war to trigger a general conflict. 


\section{Advantages of the multipolar system for stability}

In contrast to these arguments, some scholars favour the multipolar system, arguing that this pattern has advantages which make it more stable as a system. The most obvious effect of an increase in the number of independent actors is an increase in the number of possible pairs or dyads in the total system. The more states that share power and influence with each other, the more opportunities there are for interactions which force states to inhibit their actions to non-alliance nations due to its alliance partners' different relations (Deutsch Karl W. and David Singer J., 1964, p. 392). It means that the interdependence of states is higher compared to that of bipolarity so states have to carefully think about their responses to the actions of the other states in the system. Furthermore, with more than two great powers, world politics would not be a zero-sum game (Deutsch Karl W. and Singer David J., 1964; Rosecrance, 1966). In other words, the gains of a state or a state group would not be equal to the losses of the other. This diminishes the tendency to pursue a conflict up to and over the threshold of war.

The second argument in favour of a multipolar system is the idea that reduced attention is paid to other states (Deutsch Karl W. and Singer David J., 1964; Rosecrance, 1966). "As the number of independent actors in the system increases, the share of the attention that any nation can devote to any other must of necessity diminish" (Deutsch Karl W. and Singer David J., 1964, p. 396). For example, a three state system will produce two possible dyads and any state will have a 50 percent share of attention on the part of any other. In a four state system, this figure will be 33 percent and with five actors, the figure will be 25 percent. A smaller share of attention helps to reduce the dangers of mutually reinforcing antagonism between two states. 
"It shows that the average share of available attention for any one conflict drops sharply as soon as there are more than five such centers; and it further suggests that the stability of the system may depend critically on the critical attention ratio" (Deutsch Karl W. and Singer David J., 1964, p. 399). This implication reduces the probability of escalating conflict because in a bipolar system, a 10 percent increase in the arms spending of power A must be answered by an equal increment in the arms of $\mathrm{B}$, and the escalation process may proceed at a 10 percent increment for each cycle. However, in a world of four nearly equal powers, the share will be only 5 percent. In general, every increase in the number of powers would slow down the escalation of conflict because states have to pay attention to the attitudes of many states or align to other states to keep balance of power in a system.

Finally, the weakness of multipolarity in terms of the diffusion of nuclear weapons can be limited by the high costs of conflicts (Mearcheimer, 1990; Waltz, 1981). As Mearsheimer has argued "Nuclear weapons seem to be in almost everybody's bad book, but the fact is that they are a powerful force for peace. Deterrence is most likely to hold when the costs and risks of going to war are unambiguously stark. The more horrible the prospect of war, the less likely war is" (Mearsheimer J. J., 1990, p. 38). The two atomic bombs dropped on Hiroshima and Nagasaki by the US in 1945 struck not only Japan but also caused consternation among the world's communities (Ngọc, 2012; The United States Goverment, 1946; Pennsylvania State University, 1946). That was one reason in leading to the "Pacifist Constitution" of Japan later (Hughes, 2006; Umeda. S, Article 9, 2006). 


\section{Conclusion}

From the above arguments, we can see that realists who argue for or against multipolar and bipolar systems provide plausible evidence for their arguments in the longstanding debate over which system is more or less warprone than the other one. In fact, human history has experienced multipolarity 6 times and bipolarity only once (Jackson, R. , Sorense, G., 2001), and seems to support the bipolarity argument. The state system was multipolar from its inception in 1648 until the Second World War ended in 1945. Meanwhile it was only bipolar during the Cold War, but this is a long period of peace (at least between the great powers). Furthermore, twentiethcentury European history showed that bipolarity is more peaceful than multipolarity. However, if we consider European history in the nineteenth century this may not be a right answer. There was no war between any European great powers from 1815 to 1853 , and again from 1871 to 1914 and history witnessed peaceful periods of European history in the nineteenth century (Tim, D., Milja, K., Steve, S., 2009, p. 85-89). Moreover, contemporary history has witnessed Asia becoming the main hotspot in the world with the third nuclear crisis in North Korea and increasing investment on military weapons in the Southeast Asian region in spite of this being the most peaceful area in the world jn the past decades since 1980 (Bitzinger, 2010). So, whether the crisis will trigger a large war in this peninsula or even a spread of wars across the whole region, the likelihood of wars between great powers is still an open question. In fact, if war occurred or this crisis continued to last for a long time in this region, will Asia be considered the unstable region that realists predict or not? Therefore, defining what stability is and at the same time the relationship between stability and multipolarity, especially whether Asia is moving towards multipolarity or not that I have 
discussed earlier is clearly an absolutely crucial and indispensable step to addressing these issues.

\section{CHAPTER TWO: WHERE IS ASIA GOING?}

Before discussing the distribution of power in Asia, I would like to remind the reader that as a traditional concept in international relations, polarity is a description of the distribution of power within the international system. States in bipolar or multipolar models have nearly equal influence manifested in the amounts of military, cultural, and economic influence they have on the international system. However, the equality of states or superpowers today in military, cultural and economic influence is no longer explicit, but is relative. Therefore, as we consider the distribution of power in Asia today we should keep in mind that the states' relative power depends on others' relative shift of power rather than separation of ideological or historical issues. In other words, the distribution of power in Asia becomes more multipolar due to the evolution of history, especially in a globalizing age. For example, the US's relative decline in tandem with the story of China's rise has made the distribution of power in the region more multipolar and more important despite the relative disparity of power between states. Robert Pape calculated that just over half of the U.S.'s relative decline from 2000 to 2008 was caused by the spread of technology to the rest of the world (Pape, 2009). Fareed Zakaria has similarly argued that the unipolar world of 
the last two decades is waning not because of the Iraq war but because of the broader diffusion of power across the world (Zakaria, 2008).

In addition, the emergence of more global issues and non-traditional security challenges such as climate change, cyber security, and water resource security has become a burden on the top of states' shoulders and requires other states' responsibilities and abilities. As Joseph Nye argues, power today is distributed in a much different pattern which resembles a threedimensional chess game with the military and economic power being the top and the middle chessboards (Nye, 2010). Under this logic, in Asia, we should consider what the distribution of the power is among major players including China, the United States, Japan and India; and how relations between these dyads including China-the US, China-India and China-Japan are. In general, China's rise is the most important factor contributing to the shift in the distribution of power in Asia today due to other states' interactions with China in terms of cooperation and competition, and therefore will lead to changes in the foreign policies of major states as well as small countries. Among these relations, the China - United States dyad plays a prominent role in shaping regional order. More importantly, India will not accept a subsidiary role to China and as a result, this state will respond to China's rise as a peer competitor. Japan might become a pole due to its capabilities, however, this ability is uncertain because of its current and historical challenges. In a report prepared by the National Intelligence Council (NIC) of the US in November 2008, Richard Haass, president of the Council on Foreign Relations, concluded that, "the only certainties in today's world are that geopolitics are becoming more multipolar and that America will not stay on top forever" (quoted in Jisi, 2010, p. 27). Fareed Zakaria, editor of Newsweek, also envisions a "post- 
American" multipolar world where the US will no longer be in a dominant position (Zakaria, May 2008).

\section{China}

\section{Economic capabilities}

The "rise of China" has been voted the most read-about news story of the twenty-first century (Top News Stories of the 21st Century, 2012). With spectacular growth over the last three decades, China has been transformed from a failed attempt at autarkic state capitalism into the world's second largest economy behind the US after surpassing Japan in 2010 (Barboza, 2010; Breslin, 2011, p. 185). In 1990 it produced 3 percent of the world's industrial output; 20 years later this was up 19.8 percent, overtaking the US which had held the top position for 110 years. From 1952 to 1978, China's Gross Domestic Product (GDP) tripled and per capita income grew 180 percent. Industry's share of GDP rose from 8 percent to 52 percent, bringing the shape of China's economy into line with the industrial economies of the West (Elder \& Ayson, 2012). From a starting point of near zero in 1978 to by the late 1980s, "China became a member of 700 international institutions...1994 enterprises with at least some foreign investment employed over 12 million workers, accounted for 13.9 per cent of industrial output and conducted 37 per cent of China's total foreign trade" (Berger, July 2000, p. 417).

Evidence of the economic rise of China over the past decades includes it becoming the world's major creditor with a total US \$ 1022 trillion owed to China by the end of 2007 alongside the country's growing account surplus. This comes from the growth of aid and loans, and increasing contribution to 
regional and international economies (Chin, Gregory; Helleiner, Eric, 2008). China's economic influence has been marked by rescuing Asian economies from recession in the aftermath of the Asian crisis in 1997, and even the global crisis in 2008 that raised a question posed by Wang and other scholars about whether China could save global capitalism (quoted in Breslin, 2011).

Despite remarkable growth over the past decades and predictions this may continue into the future, China's economy depends upon external access to raw materials and energy supplies and relies heavily on exports and Foreign Direct Investment (FDI). In other words, China remains a global final assembly centre (Athukorala, 2009, p. 235). Therefore, while it may be true that China's GDP may surpass that of the U.S in the next 10 or 15 years, as Micheal Beckley shows, "more than 90 percent of China's high-tech exports are produced by foreign firms and consist of low-tech components; and China's quantitative advantage in scientists has not translated into qualitative advantages in innovation" (Beckley, 2011, p. 43). This implies that China still does not hold all the dollars earned and that the technological edge is ultimately not in Chinese hands. Others also argue that China's economy has been slowing, a sign that its economic model may be unsustainable.

In fact, Chinese economy has had signs of slow growth in recent years but it is not easy to see what might happen in future. In other words, there is no reason to believe the general trend will be reversed. The Organization for Economic Co-operation and Development (OECD) in a public report released in 2013 reaffirmed that China's economy will overtake the US' around 2016 (Cooper, 2013). Arvind Subramanian, a well-known economic expert, argues that by 2030, the world will become "a near-unipolar one dominated by China" (Subramanian, 2011). Accordingly, China will 
generate close to 20 percent of global GDP while the US' contribution will just under 15 percent and China's per capita GDP (in terms of purchasing power parity) will be more than half that of the United States and greater than the average per capita GDP around the world.

In sum, by 2030, China will become the dominant economy in the world in which there will be no states catching up as peer competitors (Subramanian, 2011). This projection is also similar to the prediction of the World Bank which has modelled future economic multipolarity in which China will contribute about one-third of global growth by 2025 , far more than any other economy (World Bank, 2012). If negotiations on a free trade agreement between China and Japan and South Korea are successful, positive prospects await China's economic development in terms of the impact on other economies in the region (Chris Elder, Robert Ayson, 2012).

\section{Middle income trap, gap between the rich and the poor}

One of the economic and social challenges China faces is the gap between the rich and the poor. There is also the issue of the middle income trap. According to a private study, China's Gini coefficient was 0, 61 in 2010 (Hu, 2012). This is an alarmingly high level among countries in the United Nations ${ }^{1}$. In the meantime, China's GDP in 2012 grew at the slowest rate in over 13 years. As a result, it is doubtful that whether or not China can escape the trap that affects most middle income countries get trapped, at least at a certain period of their development. However, some studies show that China

\footnotetext{
${ }^{1}$ The Gini coefficient measures the wealth gap on a scale of 0 to 1 . The higher the figure is, the greater the inequality is. A figure above 0.4 usually marks strong inequality. (http://english.caixin.com/2012-12-10/100470648.html).
} 
can escape it due to its advantages such as "a healthy share of hightechnology products in its exports, and a population with better education than other middle-income countries" in comparison with other middleincome countries (Schuman, 2013).

\section{Military capabilities}

Economic development has created more opportunities and essential conditions for China to develop its military capabilities. Chinese defense spending has also increased over past decades. The military budget doubled from 1989 to 1994, 1994 to 1999 and again from 2005-2009 (Beckley, 2011) and accounts for $2.5 \%$ of its GDP (Dobbins, War with China, 2012, p. 8). China's military expenditure increased from \$US37 billion in 2000 to $\$ 166$ billion in 2012. Between 2003 and 2012, China's military budget spending rose by 175 percent in real terms, the largest increase for the period among the top 15 countries, giving China the world's second position in the list of the top 15 military spenders in 2011 and 2012 (Sam Perlo-Freeman, Elisabeth Sköns, Carina Solmirano and Helén Wilandh, April 2013). China has developed land-based ballistic and cruise missile systems, for example the DF-21D and in the air China will also deploy the J-20 stealth fighter. China's plan requires an increase in defense spending by 11.2 percent in 2012 as the country's expanding global commitments and lingering territorial disputes drive demand for more warships, missiles and fighter planes, costing around 670 billion yuan (\$106.4 billion) (Bloomberg News, 2012). Its military modernization including naval modernization efforts include "a broad array of weapon acquisition programs, including anti-ship ballistic missiles (ASBMs), submarines, and surface ships as well as reforms and improvements in maintenance and logistics, naval doctrine, personnel 
quality, education, training, and exercises" (O'Rourke, 2012). This military modernization and expanding make the US worried about practicing its sovereign requirements and undermining the US' influence in Pacific Asia. In addition, the US is afraid of China's striving to become a global power that this state has been occupied since the Cold War.

Beyond conventional weaponry, China has advantages in exploiting the possibilities of cyber warfare to fight hi-tech wars. One of the chief strategies of China is the combination of "computer network cooperation (CNO), electronic warfare $(\mathrm{EW})$, and kinetic strikes designed to strike an enemy's networked information systems, creating "blind spots" that various PLA forces could exploit at predetermined times or as the tactical situation warranted" (Krekel, October 2009). China is developing computer network exploitation (CNE) to collect intelligence information. China's spy network aims at acquiring knowledge about the military technology of the U.S. military and the West, thereby allowing Beijing to depend less on the foreign weapons manufacturers. Moreover, this network can support the planning of the Chinese military to build a picture of the U.S. defense network, and logistical and military capabilities related to China. This source of information can be exploited when a crisis occurs. Clearly, the power to exploit cyber war-fare as one of the seven elements that constitutes comprehensive national power will be transferable into a powerful national defense (Yang, 2010, p. 149), leading to a threat to US military access to the air and sea perimeter of the Asian mainland (Chris Elder, Robert Ayson, 2012).

However, some argue that China's military does not have a global reach, and that China is only a regional power (Chris Elder, Robert Ayson, 2012). In 
other words, despite increasing efforts in military modernization over the past decades, China has still not caught up with the US in terms of not only military infrastructure but also experience (An, 5/13/2013). U.S. forces have been deployed regularly since the Gulf War while the Chinese Army (PLA) has not been operational since the 1979 war against Vietnam. The greatest weakness of China is located in the motor industry. For example, the stealth fighter J-20 (that aims at competing with F-22 or F-35 of the United States) still depends on Russian or a number of weaker domestic engines (An, $5 / 13 / 2013)$.

\section{Political system}

Pessimists are worried about the effects of China's political system on its future development because of the strict control of a one-party state that is in part "socialism with Chinese characteristics" and of course is an adversary of Western democracy (WeiWei, Spring 2013). Nevertheless, the one-party state has advantages as well as disadvantages. Accordingly, it can constrain new ideas and undermine development to a certain extent. Yet this system supports political stability (at least for the time being) - a necessary condition for sustainable economic development. China's so-called "selection plus election" political model reflects the performance of candidates and public support. Furthermore, the Confucian tradition of meritocratic governance emphasized under several administrations, especially in choosing leaders at the $18^{\text {th }}$ Party Congress, shows that China sees a meritocratic administration as clearly contributing to the successful economic and social reform of China over the past decades. One scholar argues that in "Confucian tradition of meritocracy, a state should always strive for what's called shangshangce, or the best of the best options by choosing leaders of the highest calibre.... 
China's meritocratic model of 'selection plus election' now seems increasingly in a position to compete with the Western model of popular democracy....Leaving aside sensational official corruption scandals and other social ills, China's governance, like the Chinese economy, remains resilient and robust" (WeiWei, Spring 2013). Actually, it is still too early to affirm whether or not the Chinese political model is best suited to a growing economy and can apply to other countries as American democracy has done to some degree at least. However, as argued above, at least at the present, the Chinese political model has worked effectively for the overall development of the country.

\section{Capacity for influence}

China's economic rise clearly increases its influence in the world and regional system. Firstly, it impacts on political issues in other countries and secondly it raises China's prestige and voice in the world and regional organizations. Like the US during the 1956 Suez crisis, China has also used the advantages of foreign exchange reserves as a tool of foreign policy. She has promoted overseas investment and increased overseas aid to increase her influence, particularly political influences in invested countries, especially in Africa which is rich in natural resources (Deborah Brautigam, 2010).

In the case of the South China Sea, Cambodia and Laos blocked the joint statement criticizing Beijing at the ministerial meeting of the Association of Southeast Asian Nations (ASEAN) in Cambodia in 2012, thus preserving their relative gains with China. This was the first time in ASEAN's history that members did not agree on a general statement of the meeting as the Chairman from Cambodia did not agree to include the language in the final joint statement referring to the contention of the Philippines and Vietnam 
over recent territorial disputes in the South China Sea with China. Accordingly, Cambodia insisted that such disputes should be managed bilaterally, which is also China's policy ("Asean nations fail to reach agreement on South China Sea”, BBC news, 2012; Launey, 2012). Some diplomats suggested that Cambodia had been influenced by its giant ally China. Cambodia is one of China's oldest and closest allies and economically, China is Cambodia's biggest foreign investor and an aid donor. Foreign direct investment flows are seen as a main driver of economic development and liberalization in Cambodia ${ }^{2}$ (Heng, 2012). So, Cambodia is unlikely to turn its back on the opportunities China offers from economic investment and aid.

The case of Cambodia points to the fact that China's economic rise has had a considerable influence on other governments' decisions and policies to ensure its relative gains. This also shows that the rise and fall of great powers has been primarily achieved by changes in relative economic strength (Robert Pape, 2009). That is one of reasons why scholars and research organizations attribute the shift in global power from West to East in the $21^{\text {st }}$

\footnotetext{
${ }^{2}$ Chinese leaders repeatedly visited Cambodia with several gifts since early 2012 as Cambodia holds the rotating chairmanship of ASEAN. For example, in late February, China donated Cambodia a package of equipment worth $\$ 430,000$ USD to host ASEAN Summit in Cambodia. In 3/2012 Chinese President Hu Jintao pledged to support Cambodia to become a non-permanent member of the Security Council of the United Nations. In 5/2012 China announced to donate Cambodia \$ 20 million USD to strengthen defense. In 7/2012, Chinese Foreign Minister Yang Jiechi also met with Cambodian Prime Minister Hun Sen a few days ahead of the Meeting of ASEAN foreign ministers and the ASEAN Regional Forum (ARF) in Phnom Penh. Furthermore, Cambodia and China met on the sidelines of the ASEAN meetings and the Chinese foreign minister Yang Jiechi expressed his appreciation for Cambodia's long-standing firm support for China on issues concerning Chinese core interests. Cambodian Foreign Minister, Hor Namhong expressed his thanks to China for giving a 430,000 USD aid donation to celebrate the ASEAN summit. (Trung Quốc đổ hàng tỉ USD vào Campuchia, tuoitre online, 7/15/2012. http://m.tuoitre.vn/tin-tuc/The-gioi/The-gioi/147353,TrungQuoc-do-hang-ti-USD-vao-Campuchia.ttm) (Cambodia will receive 12 military helicopters of the Chinese Z-9).
} 
century in the context of increasing economic development towards multipolarity in Asia-Pacific: the so-called "Asian miracle" (Layne, 2012; Scowcroft, 2012). In fact, the success of the Chinese economic model can influence other states as some countries and people might wish to pursue China's model of development, the so-called "Beijing consensus"3 rather than the "Washington consensus" as observed by Nye and Wang (Nye and Wang, 2009).

China's economic growth and military expansion has undoubted effects on the regional and global international system. Apart from direct influences on other countries' political behaviour, especially small and poor countries, its international clout in regional and international organizations has increased as well. Despite having no hand in shaping the form of the major international institutions in the post war, China nowadays has tried to renew these organizations aiming at its objectives and interests. For instance, China's opposition to some of the rules designed by Western states has made it impossible for the Doha Round of world trade talks to come to a conclusion (Chris Elder, Robert Ayson, 2012). Moreover, China also actively encourages changes to institutions to protect its interests as well as reduce constraints from other great powers like the United States. China's efforts to internationalize the Renminbi when in 2009 Central Bank Governor Zhou Xiaochuan called for establishing a "super sovereign" currency to replace the US dollar or a review of the global financial system

\footnotetext{
${ }^{3}$ The "Beijing consensus" was based on the Asian Miracle and it encouraged education, innovation, experimentation and sustainability. The model was not a "one size fits all" model like the Washington consensus. It did not believe democracy was the key to development. China said that the better economic model is maintaining strong state's control of key sectors, and should encourage innovation; it does not allow too much freedom to financial situation. China's economy seemed to flourish by using this model. On one side, an authoritarian government with a market-oriented economy. On other side, market economics with democratic government (quoted in (Yang, 2010).
} 
by President Hu Jintao at the G20 summit (Chris Elder, Robert Ayson, 2012, p. 5) or vetoing the US' decision to go to war with Iraq are evidence for this power assumption. Although China has benefited from the existing international order, Beijing remains suspicious of the international system dominated by the West, particularly the United States. According to Foot, Chinese "mainstream strategy analysts" have "overall perceived a consistent and malign US strategy of global domination", and consider US hegemony to be "predatory in nature" (Rosemary Foot, 2006). Dr Jian Yang (November 2008) argues that Chinese leaders are not shy in calling for a fairer international order. In his address at the United Nations Summit on 15 September 2005, President $\mathrm{Hu}$ Jintao declared that China would "actively participate in international affairs and fulfill its international obligations, and work with other countries in building ...a new international order that is fair and rational" (quoted in Yang, 2008, p. 1).

\section{"China's peaceful rise" and territorial claims}

"China's peaceful rise" is the term that was used originally by Zheng Bijian, one of the leading intellectuals since Deng Xiaoping began China's process of opening and reform, at the $16^{\text {th }}$ National Congress of the Communist Party in December 2002. The concept implies that unlike past rising powers that pose threats to other states, China will work very hard in its own way, a way that is not based on terrorism or the use of force to advocate a new international political and economic order to integrate into the international system. So China needs the help of the rest of the world in order to employ its responsibilities towards international affairs. The term "China's peaceful rise" was then changed to "peaceful development" (China's Peaceful Rise: Speeches of Zheng Bijian 1997-2005, 2005). 
"Our path is different from both the paths of Germany in World War I and Germany and Japan in World War II, when they tried to overhaul the world political landscape by way of aggressive wars. Our path is also different from that of the former U.S.S.R. during the reign of Brezhnev, which relied on a military bloc and arms race in order to compete with the United States for world supremacy.

Our brand new path relies upon the following factors, namely: relying on our own development; relying on the opening up of markets; relying on institutional innovation; relying on getting connected with economic globalization instead of being isolated from it; and relying on reciprocity and mutual benefit with other countries for the purpose of winwin relations" (China's Peaceful Rise: Speeches of Zheng Bijian 1997-2005, 2005, p.5-6).

In reality, on the one hand China's rise contributes to the prosperity of Asia due to its economic capabilities, but on the other hand, it makes the regional and international community more worried due to China's increasingly tough and truculent behaviors toward its neighbors in Asia as well as the US and the European Union. China has continuously published territorial claims overlapping the sovereignty of other states on South China Sea and Senkaku/Diafao. In the Indian Ocean, a place where nearly 90 percent of oil must cross to come into Chinese market, China has exercised the "Strings of Pearl" strategy making India worry about the potential for China to project her power in the Indian Ocean that is traditionally considered as India's backyard (Brewster, Spring 2010).

In practice, it is not difficult to see that the attitudes and actions of China are mainly driven by an aspiration for global dominance or at least regional dominance which has been supported by its economic development and military expansion. Despite a series of actions designed to meet the objections of most states regarding the territorial disputes in the region, in 
recent years China has issued new passports which include maps of overlapping claims by China, Taiwan, Vietnam, Brunei, Malaysia and the Philippines. India also has had quarrels with China over maps in passports and visa stamps. These actions have met with strong criticisms by relevant states such as the Philippines, Vietnam and India (China maps path to new conflicts in its passports, 2012).

In sum, China's expanding economy and military have resulted in an increasing international clout which leads to a new distribution of power in the world and Asian region. Nonetheless, this judging does not mean that the global aspiration or only the regional supremacy of China might become true within the next two decades. In other words, it seems not to be true as argued by some scholars (Kang, 2003; and Kupchan, Autumn, 1998) that China will dominate Asia due to its rise in tandem with the US' withdrawal from the region. That is because despite its relative decline as some have argued, the US is still an extra-regional balancer in the Asian region due to its abilities and aspiration as well as Asian states' wishes for the US' presence to constrain China's rise.

\section{The United States}

\section{The economy}

It is said that the US' power has declined in relative terms due to problems involving its economy and military; and that it will withdraw from the region with China's replacing it (Kupchan, 1998; Kang, 2003). In reality, we can see a fact that the US' economy has only declined relative to China's economic rise, and moreover, the US economy is still able to compete with China's economy. Some signs show that the growth rate of China's economy 
has slowed since 2012. As China enters the third phase of economic development (technological innovation) its growth rate will be much lower than now because growth will then rely almost exclusively on innovation (the US is about 2-3 percent), and a 7-9\% technological innovation rate is unprecedented (GlobalChinatrade.com, 2013). In addition, although the U.S. economy grew at a modest rate of over 2 percent in the last decade, this figure fails to take into account the huge profits made by overseas American firms (Aubin, 2013; LineBaugh, 2013), many of them in China (this is the converse with China's economy that has been analyzed above).

Secondly, if one looks into its economic competitiveness, the U.S. still greatly outperforms China as well as other possible challengers in almost all indicators. According to the 2012-2013 Global Competitiveness Index announced by the World Economic Forum, the U.S. ranks $7^{\text {th }}$ among 144 surveyed countries/economies while China trails at the $29^{\text {th }}$ place, behind Malaysia and Saudi Arabia (Klaus Schwab, 2012). U.S. spending on R\&D still accounts for 50 percent of the world's most advanced scientific articles (Beckley, 2011, p. 64). With regard to financial factors, the US dollar remains the world's main reserve currency, a fact which Susan Strange called structural power (Christopher May, 1996), accounting for 60 percent, with 27 percent for the Euro, and the rest for other currencies (North, 2011). Despite China's efforts to internationalize the Renminbi, it is hard to believe that it will become the world's principal reserve currency in the foreseeable future.

Being the world's number one economy, the US economy influences almost all states in Asia and globally. As for Asian economies, the US has still played an important role in maintaining prosperity and the stability as well as 
a liberal global trade and financial system in the region. Firstly, the US is one of the world's most populous and wealthy states, so the US market requires several sources of goods and products to be good in quantity and quality as well. This is especially important for several Asian economies depending on exports. In the list of the US top ten countries exporting to the US, there have been five countries in Asia including China, Japan, Canada, South Korea and Taiwan. Among them, China is the biggest exporter to US with US \$ 334 billion in 2010, exporting mainly computers (Waksman, 2012). The 10 years from 2000 to 2013 witnessed the rapid expansion of China-US trade and economic relations. Two-way trade increased 180 times growing from $\$ 2.4$ billion in 1979 to $\$ 446.64$ billion in 2011. In 2012, China's imports from US were US\$ 119.2 billion whereas China's exports were US\$ 319.4 billion, up by $8.1 \%$ and $8.2 \%$ respectively (Record High China-US Trade close to US\$ 500 billion, 2012). The most important point here is that both states are the second biggest partners of each other (Hien tai va tuong lai cua quan he Trung My, 2012). Actually, the US is focused on exports to China's growing markets, while China is seeking to buy more high-tech products from the US (Clinton, American Pacific's century, 2011).

More particularly, the United States has played an important role in driving Asian economies to enter liberal and open economic policies. The US has long encouraged its East Asian partners and important countries of the region, like China, to adopt these policies to a degree. Consequently, East Asian economies have become an economic dynamo, a global economic player and an engine of global economic growth at a time when a number of OECD countries have been growing relatively more slowly and have not been able to generate the kind of demand needed to boost global growth. The 
key role of the US in this process has been proved as a vindication of its approach (Petras Austrevicius and John Boozman, 2007).

In fact, the US is the important import market of several countries in the world, especially in Southeast Asia. As a result, as the US economy turned into recession, the export of countries was affected negatively. Some economies such as Japan, Singapore, Taiwan and Hong Kong were also in deep recession. Other economies' growth became slowed (Hong Kong falls into recession: government, 2008). The Europe economy having strong ties to the US economy was seriously impacted in terms of finance and economy as well (Fackler, 2008). Several financial organizations were broken down and created the financial crisis in some countries such as Iceland and Russia (Dougherty, 2008). The regional biggest economies including Germany and Italia also dropped into recession and the English, France, and Spanish economies also reduced their growth. The Europe zone officially was in the first economic recession since its establishment (AFP, 2008). In general, the slowing world economic growth after the 2008 crisis reduced the demand and price of oil damaging the oil production countries. This resulted in a global food crisis in 2008 (Shah, 2008). These all show an experience that the US economy's shift will impact on Asian economies and global economy as well in present and in the foreseeable future.

\section{Military capacity}

In terms of its economy, the US might be in relative decline in comparison with China and other emerging states. Nonetheless, in terms of military power, the US is still the biggest country in capacity and military spending. For example, in 2008 , the U.S defense budget was US\$607 billion which was nearly half of the world's military spending and higher than that of 
combined four major states considered as presumptive challengers including China, India, Japan and Russia and even outweighed the 27 states of the EU. Despite a fall of 6 percent in 2012, the US military spending in this year was still 69 percent higher than that in 2001 when the 'global war on terrorism' began and was still more than the combined spending of the next 10 countries (Sam Perlo-Freeman, Elisabeth Sköns, Carina Solmirano and Helén Wilandh, April 2013). Furthermore, this fall was related to a reduction in spending on Overseas Contingency Operations (OCOs) in Afghanistan and Iraq, from $\$ 159$ billion in 2011 to $\$ 115$ billion in the 2012 countries. Meanwhile, China's military budget was just one-fourth of the US' with US $\$ 166$ billion compared with America's $\$ 682$ billion (Sam Perlo-Freeman, Elisabeth Sköns, Carina Solmirano and Helén Wilandh, April 2013).

In terms of its naval force, the U.S has the ability to project power quickly and over great distances due to a big naval tonnage that exceeds the world's next 17 fleets combined. For instance, it is certain that today China, Russia, Japan, India, and the EU cannot conduct a major war 8,000 miles from their shores whereas the United States has this done twice in Iraq and once in Afghanistan in the past decade (Joffe, September/October 2009, p. 26). Not only by sea has the US military achieved a rapid response and shown the ability to acquire facilities in emergency circumstances. For example, in NATO's victory in Libya, the first lesson experienced was that NATO's members heavily depended on the US military, and needed to strengthen NATO's basic infrastructure to increase its role in global security. In this war, the US military provided 75 percent of the intelligence, surveillance, reconnaissance data, refuelling planes and dispatched 100 military personnel to the NATO targeting center to protect Libyan citizens and enforce the arms embargo (Stavridis, Ivo H. Daalder and James G., June 2012, p. 11). As a 
result, this rapid response rescued the people of Benghazi, obliterated Libya's air defense system within 72 hours, and deployed aircraft and naval vessels to enforce the UN resolution (Joffe, September/October 2009, p.11).

The US military has also played an important role for many Asian states. Japan is a good example in point. This state has no nuclear weapons and put its security under the US security reassurance since the Treaty of Mutual Cooperation and Security between the US and Japan signed in 1951. The treaty established that any attack against Japan or the United States perpetrated within Japan's territorial administration would be dangerous to the respective countries' own peace and safety. In fact, US reassurances are one of the reasons why it is believed that Japan has not rearmed significantly even though the US has urged Japan to have more responsibilities in international affairs (Betts, 1993-1994, p.56; Mulgan, October 26th, 2010).

In order to face China's rise, Southeast Asian states such as the Philippines and Thailand, formal allies of the US, and other states such as Singapore, Vietnam, India, Indonesia, Burma and Malaysia have taken advantage of US military capabilities to cope with China. Both Thailand and the Philippines have been designated as major non-North Atlantic Treaty Organization (NATO) allies. Asian states consider the US as an extra-balancer to China's counter-containment. Evelyn Goh argues that, "in Southeast Asia, indirect balancing of growing Chinese power hinges on three elements. First is the strong expectation of deterrence, particularly in harnessing superior U.S. forces in the region to persuade Beijing that any aggressive action would be too costly or unlikely to succeed" (Goh, 2007-2008, p.133). These states not only attract US military assistance, and participate in bilateral and multilateral joint exercises to strengthen their military capabilities but also 
provide the US military with bases to "further buttress US military presence superiority in the region or to demonstrate the ability to harness it, to act as a general deterrent to Chinese (or other) aggression...These balancing policies are indirect, because they "borrow" US military power, are not explicitly targeted against specific Chinese military threats, and are often undertaken in the name of other types of security interests shared with the United States" (Goh, 2007/2008, p. 133).

Despite the growth in China's military power, there is no doubt that the US remains by far the strongest military power both in the Asia Pacific region and globally. According to the appreciation of Global Firepower.com (GFP), the US ranks the first among the top of the strongest ten states in the world in terms of military strength (exclude nuclear capability) in 2012 (10 quân đội hùng mạnh nhất thế giới, 2013).

From making the comparisons in terms of economy and military, it seems that the US still has sufficient capabilities to retain its role in the Asian region as an extra-balancer. It means that the US' presence in Asia keeps a check on the rise of China's power in the region, and helps to maintain a balance between China and the US, and other states, thus preventing Chinese hegemony.

\section{Soft power}

It is said that US soft power has reduced in the aftermath of 9/11 attacks due to foreign policies under the George Bush Administration (Nye, 2004 and 2008). This is true but there is no denying the fact that US soft power is still very strong and is able to project in the Asia region and globally. Firstly, American values and culture still represent the West's liberal democratic 
values and norms. Secondly, America's Hollywood movies, McDonald's and pop culture, and advanced education and universities still attract billions of people around the world. Hollywood products are present in every corner of the planet, even in North Korea. America has the world's largest publications in terms of newspapers, and magazines such as the New York Times, Time magazine (Time) and the Washington Post). In terms of higher education, the US is still a wonderful destination of most students in the world as a study shows that "the US is home to fifteen of the top twenty universities in the world" (Beckley, 2011/2012, p. 66).

In reality, since after the September eleven attack and under the George Bush's administration, the US' soft power declined due to "hawkish" policies that led to "anti-Americanism" (Nye, 2004). However, the election of Barack Obama as the first nonwhite President and the appointment of Hillary Clinton as Secretary of state boosted the US image in Asia (Jisi, 2010, p. 37). Moreover, as Barack Obama come to power, he recognized the declining soft-power of the US, and has been determined to change the US image through reforms aimed at restoring the power, prestige and position of the United States. In his inaugural address in 2009, President Barack Obama has clearly stated policies of the new government: "To the Muslim world, we seek a new way forward, based on mutual interest and mutual respect" and he promised the United States will seek the cooperation and greater understanding between peoples (Obama, 2009).

According to a public opinion survey done by the Chicago on Global Affairs in 2008, America's soft power in Asia greatly exceeds that of China. The US was ahead of China in four categories including politics, human capital, economics, and diplomatics (Jisi, 2010, p. 37). 


\section{The US pivot policy}

Facing the challenges from China's rise and urgent demands of economic interests from the Asian region, the US decided to turn towards the AsiaPacific through the "pivot to Asia" regional strategy that was marked by the statements of President Barack Obama and the new Defense Strategic Guidelines, and especially a major article written by the former Secretary of State Hillary Clinton in 2011. In her article, the Secretary of State claimed that the US will invest time and energy in the Asia Pacific region to sustain its leadership, secure interests and advance its values. Furthermore, Hillary Clinton also emphasized the US role in maintaining peace and security across the Asia-Pacific "through defending freedom of navigation in the South China Sea, countering the proliferation efforts of North Korea, or ensuring transparency in the military activities of the region's key players" (Clinton, 2011, p.57).

Despite denials from the US, China has seen this strategy as constraining the China's rise to retain America's supremacy in Asia Pacific because China's rise has threatened US dominance and favored a new distribution of power (Liu, 2013; and Han Sung-Joo, 2008). It is right as some argue that on the one hand the US will not withdraw from the Asian region and allow China to replace it (White, 2012; Betts, Winter, 1993-1994; Choi, 2010-11 and Friedberg, 1993-1994). On the other hand, the US cannot cope with China's rise on its own (White, 2012). Instead of doing so, the US inevitably needs to pay renewed attention to Asia-Pacific due to its dominance and economic interests in this region. Therefore, China's rise and her ambitions surely face challenges from US constraint in the region as well as increasing demand of cooperation. Actually, it is more likely that Asia will be a bipolar system and 
might be more stable if the order of the system is only affected by these two great powers. However, in reality, China's rise is constrained by another emerging power in Asia as well. With the economic potential, increasingly naval power and historical ties, it is likely that India will become the third candidate for great power status in Asia in the long term.

\section{India}

After World War II and especially in the aftermath of early disappointment in trying to unite ASEAN in the 1950s, India developed a non-aligned policy making the Indian military isolated from the outside world, including the Soviet Union. However, there has been a shift since the collapse of the Soviet Union and the end of the Cold War as India was facing economic challenges and threats of regional dominance coming from the rise of neighboring China. In the re-orientation of its foreign policy, India focused on promoting foreign investment and improving its military capabilities, especially naval power to constrain the Chinese naval expansion. In order to begin the process of economic and political reform, India decided to focus on the Southeast Asian region with the "Look East" policy that was launched from the mid-1990s and has matured in the last few years (Mohan, 2008). Apart from the economic element, India has other advantages including an increasingly capable Navy, large population and global and regional aspirations existing from history, compared with other states in the region. It is likely for India to be the third candidate for the regional great power position in the coming decades, along with the US and China. 


\section{Economic capabilities}

In fact, in past decades, India has been considered as the least important factor among major powers contributing to shaping the Asian order. Nevertheless, the recent re-emergence of India that has been marked by sustainable economic growth with around 8 percent rate per year during the first decade of the $21^{\text {st }}$ century has seemingly reduced the skepticism about its role in Asia's security.

India entered into economic reform focused on the liberalization of foreign investment in some keys areas; reforming the tax system and the delivery of subsidies since 1985. The process of economic liberalization pursued more vigorously since 1991 has brought about a significant success in India's more competitive economy. As a result, economic growth has gradually increased over the past decades with 5.5\% annual growth rates between 1985 and 1990, 6.6\% between 1992 and 1997 and up to 9.6\% since 2002. The growth rate of the 2005-2008 period continuously rose over 9\%. Real per capita income has increased at an average rate of around $4 \%$ during the 15 year period from 1985 to 2000 , and the incidence of poverty has declined from around $44 \%$ in mid-eighties to around $26 \%$, while the life expectancy at birth has risen significantly from 48 years in 1985 to 64 years in 2000 (Dholakia, 2001; Anh, 2011).

As for purchasing power, India has jumped to fourth in the world behind the US, China and Japan. With a total gross domestic product estimated 1,235 billion, India ranks $10^{\text {th }}$ in the world and third among Asian's economies (Anh, 2011). Recently the Organization for Economic Co-operation and Development (OECD) published a report that said that around 2020, India 
would probably surpass China to become the world's biggest economy (The Indian Express, 2013).

\section{Population size}

There is also a fact that the gap between the poor and the rich, and the poverty rate due to the large population in India are still high. Therefore these problems need to be attacked as a main work of India's rising economy in the future. Nonetheless, people who believe in India's further economic potential assert that the potential for strong sustained growth of the Indian economy is still high due to its young population and high savings rate. As for population size, in the period of 1960-2000 India's population rose from 448 million to 1.04 billion - and to 1.21 billion in 2010 (Bloom, January/2011). The United Nations Economic and Social Commission for Asia and the Pacific (ESCAP) projection and United States Census Bureau estimate that India's population will have reached 1.5 billion by 2025 and for the first time in history, India will surpass China to be the most populous country in the world (Roberts, 2009). As Virmani shows, "with per capital income/GDP almost identical, the relative size of population is the primary determinant of relative economic of size. Thus over the medium -long term relative population is an important determinant of size" (Virmani, 2005, p.4). So, India's relative power will inevitably rise over time, especially as India's population will overcome China's in coming decades.

India's population will enter the gold period with growth rate of a relatively young and working-age population exceeding that of total population (P.N. Mari Bhat, 2001). The dependency ratio of India's population-the proportion of children and old people to working-age adults-is one of the best in the world and will remain so for a generation in the future in India. 
Especially, the quality of population has been increased significantly since 1950. For example, the infant and child mortality rate has fallen sharply with 70/100 and 75/1000 respectively (Bloom, January/2011, p.7). Thus, the potential population and the increase in its quality will contribute effectively to the working productivity of the society (Dholakia, 2001; India's economy: India's surprising economic miracle, 2010).

\section{Military capabilities- Naval power}

India, "as an aspiring great power, has over the past decade put considerable resources in building up its military capabilities" (Bitzinger, 2011, p.32). In terms of military spending, India ranks as the world's seventh biggest spender in 2012. Experts envisage that by 2020 India will have overtaken Japan, France and Britain to come in fourth of the world in military spending (India as a great power, 2013). In Asia, Indian military ranks as second, only behind China in terms of size (10 quân đội hùng mạnh nhất thế giới, 2013).

Over the last five years, India has been the world's largest weapon importer. In comparison with Japan, in spite of a US\$ 13.2 billion bigger budget, Japan's military expenditure fell 3.6 percent in the 2003-2012 period, while India's military expenditure increased 65 percent in the same period. India's defense budget has risen to $\$ 46.8$ billion in 2013 . This state currently has negotiated a $\$ 12$ billion deal to buy 126 Rafale fighters from France and the deal is about to be successful. In addition, "India has a nuclear stockpile of 80 or more warheads to which it could easily add more, and ballistic missiles that can deliver some of them to any point in Pakistan" (India as a great power, 2013). The state has recently tested a missile with a range of $5,000 \mathrm{~km}$ (3,100 miles), which would reach most of China (India as a great power, 2013; An do tang suc mang quan su doi pho voi Trung Quoc, 2013). 
Apart from remaining an Army-heavy force oriented toward a ground war with Pakistan, the Indian military increasingly stresses long-range surveillance and intelligence, force projection, and expeditionary warfare that favors the Indian navy (IN) to take responsibility for a "constabulary role" in the Indian Ocean (Bitzinger, 2011, p.32). The goal of naval power build up is that by 2020 India plans to have a "160 plus-ship navy, including three aircraft carriers, 60 combatants, including submarines, and close to 400 aircraft different types" (Ladwig, 2009, p. 91). In order to support for this objective, the Indian Navy's share of total military budget went from 11.2 percent in 1992-93 to 18.3 percent in 2007-08 (Ladwig, 2009, p. 91). India is among a few countries in the world and inevitably the only one in Asia Pacific so far to operate large sized aircraft carriers (Bitzinger, 2011, p. 32). If we compare this with the Chinese naval force, India's Navy might be not better but in terms of working experience, like the US, the Indian' Navy force is appreciated more experienced than that of China.

\section{India's re-emerging influence and "Look East" policy}

After World War II, India tried to unite and consolidate Asia into a united region so-called the "Asian Federation". This strategy was operated through an Asian Relations Conference (ARC) convened by the Prime Minister of the interim government, Jawaharal Nehru in Delhi in March 1947. However, the conference then failed due to other states' skepticisms and worries on whether India and China at that time would pose threats of "Asiatic imperialism" (Mohan, 2008, p. 5 and Mohan, 2011). After the failure of this attempt at Asian unity and consolidation, India turned to a non-alignment strategy resulting in a weak Indian military and poor economy. Actually, since the collapse of the Soviet Union, India realized its advantages and 
disadvantages in terms of geopolitics as well as political and diplomatic opportunities. Thus, Indian leaders perceived that this state needs to reform its economy and the first regional initiative was towards Southeast Asia through the "Look East" policy ${ }^{4}$ (Mohan, 2008, p. 45). As India began to reorient the foreign policy, it is believed that promoting the economic and political relationships with states in Southeast Asia is only a step in the plan to resurface the aspiration "from Aden to Malacca" under the Raj time of British India that clearly manifested the aspiration to control littorals "from the Swahili coasts to the Persian Gulf and eastwards to the Straits of Malacca" (Ladwig, 2009, p. 90). In other words, the security of British commerce in the Far East and the trade routes to Australia and New Zealand all depend on India's power (Ladwig, 2009; Mohan, 2008). It is also believed that this ambition re-emerged since about 1990s after the collapse of the Soviet Union as India tried to acquire an ambitious naval program as Defense Minister George Fernandes declared that India's “area of interest... extends from the north of the Arabian Sea to the South China Sea" (Asia Times.com, 2000). Some Indian leaders have drawn a close connection between India's maritime ambitions and its destiny as a great power. As former Indian Foreign Minister, Pranab Mukherjee, commented,

"after nearly a millennia of inward and landward focus, we are once again turning our gaze outwards and seawards, which is the natural direction of view for a nation seeking to re-establish itself, not simply as a continental power, but even more so as a maritime

\footnotetext{
${ }^{4}$ In order to understand the "Look East" policy as well as the success of this policy, see Walter C. Ladwig III (2009): Delhi's Pacific Ambition: Naval Power, "Look East," and India's Emerging Influence in the Asia-Pacific, Asian Security, 5:2, 87-113; see C. Raja Mohan (2008): India's Geopolitics and Southeast Asian Affairs, pp. 43-60 (Article) and see C. Raja Mohan (2011): Great powers and Asia's destiny: A view from Delhi, CSS Discussion Paper 10/11, pp. 1-15.
} 
power, and consequently as one that is of significance on the world stage” (Nizamani, 2012).

In order to realize its ambitions as a naval power, India has expanded not only economic relationships with Southeast Asian states but also enhanced military, especially naval, cooperation with these states. For example, for the first time in history, India convened an Indian Ocean naval conclave in February 2008 only with presence of states from South Africa to Australia and excluded the US, China and Japan (Mohan, 2008, p. 7). In 2009, in his article, Ladwig admits that although "the Navy is unlikely to reach its ambitious goals before the mid-2020s, it already possesses the ability to conduct meaningful operations beyond the Indian Ocean” (Ladwig, 2009, p. 93).

Over the past almost 20 years, India has steadily expanded and strengthened its relationship with ASEAN in terms of economy, politics, diplomacy and security as well. India's re-emerging influence and the "Look East" policy mainly are driven not only by its geography, economics and history ties but also by the Chinese neighbor (Ladwig, 2009, p. 88). Before recently assertive actions from China such as claims of territorial sovereignty in Southeast Asia Sea and the Senkaku/Diafao dispute as well as the "string of pearls" strategy of China in the Indian Ocean and the provision of weapons to Pakistan, India suggests that China is projecting power into the Indian Ocean. Therefore, India's Foreign Minister used to describe the rise of China as one of India's foremost security challenges (Times of India, November 5, 2008).

In sum, India has the ambition to affirm its status as a great power in the region, especially the sea route in the Indian Ocean because of economic 
interests and the geopolitics rivalry. As Alfred Thayer Mahan asserts, "whosoever controls the Indian Ocean, dominates Asia. In the $21^{\text {st }}$ century, the destiny of the world will be decided upon its waters" (quoted in Scott, 2006, p. 109). This factor becomes more important as we look back in history to see that India desires autonomy and independence in implementing its foreign policy because of the memories of colonial rule for 200 years, defeat in the 1962 war and a realist approach after the Cold War due to the distribution of power leading to "self-help" strategy to protect its security (Sumit Ganguly \& Manjeet S. Pardesi, 2009). Therefore, an increasing naval power like India might choose a balance of power instead of adopting a subsidiary role to other states, especially towards China, as the relationship between India and China still remains one of mistrust and misunderstanding (Mohan C. Raja, 2011, p. 5). It seems to be that with its increasing international clout, and economic and military capabilities, India would treat China as a peer to share the dominant role in the Asian region (Chris Elder, Robert Ayson, 2012).

\section{Japan}

\section{Economic growth}

Although Japan used to be an economic great power in the late 1980s and considered as a new economic model, representing a pattern of so-called world capitalism in the future, its economy has dropped into serious recession. If we assess the power balance among China, Japan, the US and India, the trends are definitely not in Japan's favor. 
Japan has the third largest economy in the world, behind the US and China, but it reduced in size by 3.5 percent in 2012. Over the last 15 years, Japan has faced minus growth in two continuous quarters no less than five times. The economic recession of Japan has been expressed most clearly in terms of a reduction in exports, trade balances, current account and very heavy loss of big companies. In the late 1980s, Japanese stocks were the most expensive in the world but the majority of them were the result of a massive bubble in real estate and finance. That bubble burst, starting in 1990, and saw the Nikkei fall from 39,000 points to 9,000 points today (Chiến, 2012). The 2012 surplus of the current account in Japan remained at a record low with -437.30 billion JPY in January of 2012 (Tradingeconomics.com, 2012 http://www.tradingeconomics.com/japan/current-account). As a proportion of its GDP, Japan has the highest debt ratios in the world. U.S. public debt is around 100\% of GDP, Italy: 120\%; Greece: 150\%, while that of Japan is $230 \%$, more than the total debt of all 17 euro zone member states combined (Chiến, 2012 and Nguyet, 2013).

Despite some faster growth in the early half of 2013 due to the "Abenomics" policy of Prime Minister Shinzo Abe, with major policies including the monetary easing, financial flexibility, and private investment promoting (Nguyet, 2013), it is still too early to affirm success of this policy. Japan's trade deficit still has continued for the 11th consecutive month with 993.9 billion yen of last May, up 9.5\% from the same period last year. Capital investment fell by $0.3 \%$ in the first quarter of 2013 compared to the last three months of 2012 (Tradingeconomics.com, 2013, http://www.tradingeconomics.com/japan/balance-of-trade). 


\section{Military capabilities}

Japanese forces, including 225,000 permanent personnel, numbers $1 / 10^{\text {th }}$ that of China and a fifth of North Korea. Japan's armed forces are equipped with modern weapons and expensive frigates mounted with the Aegis Ballistic Missile Defense system in response to missile launches by North Korea. As for its air force, Japan has 202 aircraft including F-15J DJ (157 and 45), 67 F-4EJ, F-93 2A and B (62 and 31), and 13 RF-4EJ reconnaissance planes. The quality of its air force is likely to increase further because Japan is going to buy 42 F-35 interceptors from America. Furthermore, Japan has four helicopter-carrying destroyers, nine guided-missile destroyers, 34 destroyers, and 18 diesel-electric submarines. A large number of these ships (two of the guided-missile destroyers, 13 of the destroyers, and nine of the submarines) have entered service since 1995, making this a very modern force. In general, the Japanese Navy and the Chinese Navy rank the second and the third in the world, bettered only by the U.S. Navy. Japan could have a working nuclear weapons capability in one year should it decide to. Another common understanding is that Japan's armed forces are better equipped, better trained, and more modern than the PLA (Jisi, 2010, p. 31).

Realists have predicted that Japan will rearm to become a great power in its capabilities. In fact, before China's more aggressive rise, the Japanese government had designs to gradually change investment in and exploration of military power, particularly after Prime Minister Shinzo Abe came to power for the first time in its history. In terms of defense expenditure, Japan already ranks high at the top five of the 15 countries with the highest military expenditure in 2011 (SIPRI Military Expenditure Database, 2011 http://www.sipri.org/databases/milex/). In 2013 Japan's defense budget 
increased 0.8 percent to 4.68 trillion yen (US\$ 51.7 billion) for the first time in 11 years. The Coast Guard budget will go up 1.9 percent to 176.5 billion yen, its first expansion in six years (Reynolds, 2013). The official aim of increasing the defense budget is to serve regional stability. As Japan's Defense Minister said: "We believe it is essential to build up a defense posture that will contribute to the enhancement of regional peace and stability. This is why the Japanese government has increased its defense budget for the ... 2013 [fiscal year], the first time in 11 years, and also increased the number of SDF [Self Defense Forces] personnel for the first time in eight years," (Sieff, 2013). Despite Japan's potential military role however, the major military obstacle is the fact that Japan does not have power projection capabilities to become a "normal" great power.

Firstly, under a pacifist constitution, the Japanese armed forces - also known as the Self-Defense Force (SDF) does not have its own aircraft carrier strike direction or long-range bombers (Umeda, Article 9, 2006). In addition, it has not been tested in battle because it has not participated in armed conflicts since its defeat in World War II (Linh, 2012). Secondly, Japan also faces a major political/legal obstacle. Since the defeat in 1945, Japan has been isolated by choosing a strictly defensive posture (Kang, 2003). In fact, Japan's efforts in the 1980 s to build a carrier were scrapped after political protests (N.D.Arora, 2010). Moreover, Japan also has a very strict no nuclear weapons policy. Being the only country which has suffered nuclear attacks, Japan has a self-imposed ban on possession of nuclear weapons and has become dependent on the American nuclear shield. When Prime Minister Shinzo Abe came to power, his cabinet set up an attempt to revise Article 9 in the Constitution of 1947 that "renounces war and prohibits Japan from maintaining the war potential" (Umeda, Article 9, 2006, p. 1 
www.loc.gov/law/help/JapanArticle9.pdf). Nevertheless, it will take a long time to achieve that goal which might not be approved by Japanese citizens in the foreseeable future (Kang, 2003). In addition, it is unlikely that Japan will soon give up the reassurance afforded by its military alliance with the US that has arguably been instrumental in preventing Japan going nuclear (Chris Elder, Robert Ayson, 2012). However, as Robert Jervis writes, "Minds can be changed, new leaders can come to power, values can shift, new opportunities and dangers can arise" (Robert Jervis, 1978, p. 105). This view might apply to the case of Japan under the Shinzo Abe's administrative. Nevertheless, if Japan wants to be a normal great power the dream was more realizable some decades ago when the Japanese economy enjoyed robust growth and Tokyo had many reasons to doubt the US commitment to its defense (Kang, 2003). At present, and in coming decades, the truth might be far from that wish due to economic decline. As Lam argues, Japan today is different from other great powers which wield both "hard" and "soft" power - it lacks the will and capability to exercise "hard power" (Lam, 2007, p. 354).

\section{Soft power}

Since World War II, Japan has chosen soft power as one of the ways to expand its influence. Actually there are numerous reasons for Japan to develop soft power. First of all, after being defeated in World War II, Japan has not focused strictly on military ambitions due to "pacifist constitution and residual pacifism among Japanese" (Lam, 2007, p. 350). Instead it prioritized economic growth. Secondly, facing the return of the United States to Asia as well as the rise of China and these two powers' increasing 
influence in South East Asia, Japan has no other option than balancing against them with soft power strategies (Lam, 2007).

In fact, Japan has achieved several successes in terms of culture, official developmental aid and foreign policy in Southeast Asia. The country has developed and introduced numerous cultural products to the world in general and to South East Asia in particular. For example, Japan Cool is a concept about the attraction of Japan's pop culture. With this concept, Japanese culture can be considered as a form of national power (McGray, 2001). Other traditional customs and values such as Karaoke, Sushi, manga (comics) and anime (cartoons) are welcomed and easily accepted in Southeast Asian countries (Lam, 2007). Since 1974 Japan has organized and sponsored the Ship for Southeast Asia Youth Exchange Program. The Program includes around 400 members, who are youth representatives from Japan and ten countries in Southeast Asia, participating in exchange activities on a ship from Japan to five destinations around the region. This program has indeed contributed effectively to the promotion of friendship between Japan and Southeast Asian countries.

In terms of official developmental assistance, the Japanese government is the second largest aid donor in the world. To Japan, Official Development Aid (in the form of grants and loan aid) assists the purpose of promoting economic development, strengthening economic interdependence and maintaining political stability (Hook, 2011). And regarding foreign policy, the Fukuda Doctrine has been the official blueprint to Japan's foreign policy towards Southeast Asia since 1977 (Lam, 2012).

Japan's soft power also has its limits, "lacking a CNN or BBC-like institution to project its voice globally" (Lam, 2007), and having a shrinking 
population and resistance to immigration (Nye, 2005). In addition, "Japanese is not a global language" (Nye, 2005). According to one author, "Japan's meager English-language skills make it difficult to attract international talent to its universities and Japan does not represent any universal values and ideals while certain Western nations, especially the US, champion human rights and democracy" (Lam, 2007). Finally and not least, while Japan is considered as a soft power state in eyes of American and Asian states, it lacks soft power towards China and South Korea due to historical problems and territorial disputes (Lam, 2007, p.360 and Nye, 2005).

\section{Conclusion}

In looking ahead at the evolving power balance among China, the US, India and Japan over the next years, it seems to be that China's power and international clout will continue rise rapidly; the US' capabilities will have remained powerful enough to take part in leading the Asian region; whereas Indian economic potential development supported by the gold population will help this state build up its great power status in this region. However, Japan's capabilities will be limited due to its economy, pacifist Constitution and the US' security assurance to become a normal great power.

As for China, despite some objections from neighbor states, in terms of economic interests, it is difficult for other states, especially states in Southeast Asia relating to territorial disputes with China to turn their back on the economic opportunities China brings for them. Meanwhile, instead of dealing with the impact of China's rise, it is prudent for other Southeast Asian states to welcome the presence of the USA as a counterbalancing influence. Along with its economic interests, that is main reason why the US 
will not withdraw from the region in the foreseeable future to ensure its political goals and will continuously be considered as the extra-balancer in Asia.

In comparison with Japan, India seems to be still growing economically. Indian economic growth has increased steadily over the past years and there is no sign of it stopping. Moreover, India is predicted to overtake the US and China as well to become the biggest economy in the coming decades. In contrast to this, Japan's economy has expressed signs of slowing down. In general, economic experts predict that it will be hard for Japan to recover its economic position in coming years (Singh, 2012; World Economic Situation and Prospects 2013, 2013; and World Economic outlook, 2012). Virmani shows that "Japan has passed the peak of its potential power and will be on a declining trend over this century. Its power potential has already fallen below that of China and will fall below that of India within the next 20 years" (Virmani, 2005, p. 15-16). As William H. Overt argues, Japan's unique economic model created the country's economic miracle but has led Japan to the edge of collapse (William H. Overholt, 2002).

Furthermore, India has more advantages than China and Japan in terms of population size which is a necessity for further economic development. In comparison, India's population is entering a golden period with a young and growing workforce while Japan's is declining and aging quickly; and China's will shortly start aging because of its one-child policy.

China's population is aging faster than any state in the world. Accordingly, it is estimated that by 2050, the ratio of the percentage of the population over the age of 65 years in China will be more than 15 percent leading to a lack of pension coverage, the so-called " $4: 2: 1$ " phenomenon. The concept means 
that increasing numbers of couples will be solely responsible for the care of one child and four parents in China within the next decades (Hesketh, T. and Lu, L. and Xing, Z.W, 2005). Another study proves that by 2050, about 430 million people - accounting for one third of the population - will be retired. The ratio of workers in comparison with that of retirees decreased rapidly, from 10/1 in 1990 to 6/1 in 2000 and will be 2/1 in 2040 (Trung Quốc: Dân số già và những hệ quả tất yếu, 2007). Population aging therefore will lead to a series of issues affecting and threatening the Chinese economy such as the supply of working force and the need to balance the basic human rights of reproduction with population growth - especially as China is considered as a manufacturing center and a supply of cheap and abundant labor (Hesketh, T. and Lu, L. and Xing, Z.W, 2005).

Japan's population dropped by around 284,000 in the 1950 s to an estimated 127.5 million by October of 2012 with around 24 percent aged 65 or over and only 13 percent aged 14 or under. Japan is one of the fastest aging nations in the developed countries (Demetriou, 2013). This aging population inevitably will impact on the economic productivity in coming years in Japan whereas India's potential economy and good age population will be able to favor Indian great power status in the foreseeable future.

Compared with India, it is difficult for Japan to overcome its current and historical challenges to become a normal great power. Apart from the economic and aging population issues, Japan has to face the pacifist Constitution and its dependence on US military assurance. Recently, the US has reaffirmed its assurance towards Japan under the bilateral security treaty between the US and Japan (Vietnamplus, 2013). In addition, in Defense White Paper 2013 published in July, while emphasizing China's challenges, 
Japan also stressed and highly appreciated the US-Japan alliance's key role in ensuring regional security and stability (Vietnamplus, 2013). These events partly show the fact that it is difficult or at least will take a very long time for Japan to escape the US' security asurance and not be dependent on the US.

In sum, despite some economic progress since Shinzo Abe came to power, it is too early to say that the Japanese economy is recovering (TradingEconomics.com, 2013, http://www.tradingeconomics.com/japan/report) and that is the key factor contributing to overall development of a state. So, the chances of Japan becoming a normal great power, as argued earlier, will be limited due to its economy, pacifist Constitution and the US' security assurance. As a result, it is more likely to envisage that Asia will be dominated by three leading powers including China, the US and India, instead of four leading powers including Japan. 


\section{CHAPTER THREE: MULTIPOLARITY AND STABILITY IN ASIA}

In this chapter, I would like to discuss how multipolarity will affect stability in the Asian region. In other words, if the Asian region becomes more multipolar, will it become more stable or unstable?

A more multipolar Asia might be driven mainly by China's rise and the dominance of other major powers including the US and India in the next twenty or thirty years. By that time, China will be the strongest power and India might be the weakest one, and the size of the combination between the US and India will be larger than that of China (Virmani, 2005). The implications for Asia's future of this shift are not certain however.

As mentioned in chapter one, the term stability refers to two factors including (1) war/conflict avoidance and harm avoidance and (2) obtaining and returning to the equilibrium of the system. To examine the stability of the Asia-Pacific, Robert Ayson also offered five types of stability as follows: (1) the avoidance of major war; (2) the stability of the distribution of power; (3) the stability of institutions and norms; (4) political stability within countries; and (5) economic stability.

In my opinion, the issues being addressed in this thesis are related to the relations between multipolarity and its effects on the stability of the system. This means that to consider the stability of the region in the context of Asian multipolarity, we should take into consideration the most relevant factors influencing the establishment of the model. In other words, how the increase in the number of major actors in the multipolar model compared to the 
bipolar and unipolar models can affect Asian stability. In balance of power theory, the multipolar system can lead to competition and even wars between great powers due to the alignment of some great powers against the others. That is one of the reasons why most scholars only focus on estimating the likelihood of major great powers' wars to measure the Asian stability. Under this logic, I have decided to examine the avoidance of great power wars in Asia as the first element to measure the stability of the system.

However, the likelihood of the great powers' war can be controlled or limited by other factors in the process of measuring stability. In other words, this variable is insufficient to measure the duality of the system relating to how states can check and balance each other, and especially how long the stability will last that might be associated with the legitimacy of great powers. This examination allows us to understand that if the Asia region is more multipolar, will the transition from the unipolar system after the Cold War, and bipolarity (now) into the multipolar system be smooth or disrupted? Answering this question will help to prove whether the durability of the distribution of power in a multipolar Asia that is associated with the likelihood of war exists or not (Ayson, 2005, p. 197). Therefore, in order to make clear these characteristics, I will take the stability of the distribution of power into consideration in checking the prospects for obtaining and maintaining the equilibrium of the system.

In sum, under the above logic, I have decided to examine two variables including great power's war avoidance and a stable distribution of power in the context of a multipolar Asia. 


\section{The likelihood of war avoidance by the great powers}

In theory, multipolarity can easily lead to the alignment of state-actors against each other. The more great powers there are, the more potential conflict dyads and miscalculations there are. The reason is that in this model, there are many more relationships than in the bipolar model. The interests of states can overlap and intertwine within different dyads. Therefore, in order to ensure their interests, states have more options to make friends or alliances with others. They are free to go around and choose others to align with. As a result, it is more difficult for states to believe in other partners due to suspicion and misunderstanding.

In a multipolar Asia, there will be relations between dyads including the USChina, China- India, and the US-India. I argue that wars are not certain between these states in the Asian multipolar system dominated by China, the US and India because of increasing economic interdependence and calculations of states' national interests.

\section{The US- China dyad: a mix of competition and cooperation}

In regards to the US - China dyad, it is difficult for a war to develop between these two great powers. Clearly, the relationship between China and the US is a complicated one of increasing and established powers reflected in terms of economic, political and diplomatic interactions. Generally speaking, this involves a mix of cooperation and competition (Friedberg, 2000b).

In terms of historical evidence, these two great powers are in contention for Taiwan, Hong Kong and South China Sea's territorial integrity and national sovereignty; Tibet's human rights; and other domestic and international 
issues' tensions such as the US-Japan traditional alliances, the North Korea crisis and the freedom of navigation issues.

Firstly, China regards Taiwan and Tibet as part of China whereas on the one hand, the US recognizes one China, but on the other hand, the US has been willing to give military aid to Taiwan aiming at preventing China's forceful reunification. Therefore, in China's view, this support prevents unification of Taiwan into the mainland. As for the Tibetan issue, the US ceased financial support for the Dalai Lama in 1971. Nonetheless, the relationship has been rekindled since 1980s as Tibet became a human rights concerns (Oksenberg, 1997). However, these differences have not become main reasons for competition between the US and China. In fact, American support of Japan and the freedom of international navigation issues are more difficult for the US-China relationship.

American support of Japan as well as military ties between these two states has raised suspicions in China. China and Japan have an ongoing territorial dispute on Senkaku/Diafao which has been increasing in tension in recent times. Supported by assurance from the US, Japan sees Washington as a strong tool to contain China. In the meantime, the US considers Japan as the most loyal ally in Asia to face challenges in the Pacific-Asian region as US' influence declines in the region. The US and Japan see the North Korean threat and the growing Chinese military presence in the region as common challenges. As Viktor Pavliatenko believed that "The USA wants to strengthen this alliance. As Hillary Clinton said recently, "we have returned to the Asia-Pacific Region to stay". The USA has lost much of its clout in the region because of China. The USA is trying to develop relations with the ASEAN but this association has its own relations with China. Japan remains 
the US' most reliable partner." (Quoted in The USA and Japan intend to drill China, The Voice of Russia, July $\left.18^{\text {th }}, 2011\right)$. In fact, the deepening of operational cooperation and capabilities in the US-Japan alliance and their commitments to cooperate on missile defense in the region under the USJapan mutual security treaty has worried China. So, Chinese media recently have raised questions about exercises between the US and Japan. It is true that the US-Japan relationship creates difficulties for China (Gui Yongtao, 2010).

The third confrontation between the US and China lies in views of freedom of international and regional navigation. Since 2010, the US has always affirmed its interests in the South China Sea in ensuring the freedom of navigation and so has objected to any coercion, threat or use of force to enforce claims in the South China Sea. The U.S. is not involved in the territorial claims and sovereignty in the South China Sea but is very interested in resolving disputes in this matter. Accordingly, US leaders have emphasized that any claims must always rely on international law, including the International Convention on the Law of the Sea (UNCLOS), as well as characteristics of soil, rocks and islands (Quỳnh, 2013). Recently, in bilateral strategic dialogue in Washington in July 2013, US President Barack Obama reminded China to resolve territorial disputes in sea and islands with neighbor states peacefully (LaoDong online, 2013). In contrast to the US, China asserts that the US has intervened in regional disputes and accuses the US of enhancing cooperation with other claimant states. In the Chinese view, the US should not intervene in these disputes and should not tilt towards any side (Nguyen, 2013). 
In sum, in spite of efforts coming from both countries over the past decades, the different perspectives of these issues have raised mistrust and misunderstanding for both. In China's view, the US pivot policy in Asia is an effort to slowdown its development and to contain it. Furthermore, China asserts that the US should not intervene in its domestic and regional affairs. Meanwhile the reemergence of China is assessed as a threat to the hegemonic position of the US due to the US' relative decline. However, it seems unlikely that the US will dominate China by using military force and it is not easy for China to trigger any wars because of the increasing economic interdependence of both states.

In terms of economic interdependence, the US and China have achieved remarkable outcomes in trade exchange over time. In the period between 2000 and 2007, US exports to China increased by 301\%. Two-way trade grew 180 -fold from $\$ 2.4$ billion in 1979 to $\$ 446.64$ billion in 2011 . The most important point here is that both states are the second biggest partners of each other (Hien tai va tuong lai cua quan he Trung My, Nghiencuubiendong.vn, 2012). China is the world's second biggest economy behind the US but currently holds upwards of \$ 1.1 trillion in US debt. Given such a situation, it seems to hold that "China gains greatly from its economic relationship with the US, but arguably the dependence of the US on China is greater" (McDougall, 2012, p. 7). At the same time, Chinese leaders also perceive a weakness in that the Chinese economy is now so dependent on external resources it might be unsustainable to the point in Premier Wen Jiabao's words of being "unbalanced, unstable, uncoordinated, and unsustainable" (Beckley, 2011, pp. 61-73; Chang, 2012; Ian Bremmer and Evan A. Feigenbaum, 2011). In the case of any war occurring between the 
two great powers, both states will be damaged economically due to economic disruption as the theory of economic interdependence assumes (The USChina business Council, 2009; Clinton, 2011; Lu, 2001; Barbieri, February 1996). This economic interdependence between the two great powers raises the high cost of armed conflicts and so reduces benefits so much. The recent meeting between President Barack Obama and Chinese President Xi Jinping which took place in June 2013 seems to show that both rising and established powers do not want to have destructive conflicts and they wish for more positive cooperation in the future (Toàn cảnh thế giới, VTV1, 6.9.2013).

This is a reminder of the fact that a world dominated by the US and China supports the stability of the Asian system. However, the problem is that in the case of a bigger India in the future, what is likely to happen to the USChina relationship? India might be a major state playing a very important role in the balance of power in multipolar Asia, and could be considered as a key actor. Therefore, Sino-Indian relations will play a critical role in ensuring peace and stability in Asia in the coming decades. How then can the US and China work to maintain the balance of power? How will India respond to the US and China's strategies to protect its national interests and great power status in the region? In fact, the likelihood of war between these two countries will be hard to estimate. In my opinion, in the case of a bigger India, there will be at least two scenarios for the relations between the major states due to India's presence. 


\section{The US-India alliance and potential China-India conflict}

Some argue (Rosecrance, 1966; Mearsheimer 1990) that multipolarity increases opportunities for states to group and align together to prevent the dominance of a potential actor or to ensure states' interests. And of course, this combination can lead to consequences that are more difficult to calculate than in bipolarity. Without India's presence, the world would be bipolar and it will favor peacefulness by the balance of power between the US and China. Nevertheless, this balance of power might disappear in a more multipolar Asia as the US aligns with India against China.

We know that US and China relations are between a rising and an established power. In the words of the American political scientist Mike Lampton, this relationship gives rise to an image of "same beds, different dreams" (David M. Lampton, 2001). Originally, the US does not want to live with any peer competitor. In the wake of the Cold War, US policymakers remain firmly committed to this goal. "Our first objective is to prevent the reemergence of a new rival...that poses a threat on the order of that posed formerly by the Soviet Union....Our strategy must now refocus on precluding the emergence of any potential future global competitor" (Mearsheimer J. J., 2001, p. 46). In March 2012 Secretary of State Hillary Clinton also said diplomatically: "The US is attempting to work with a rising power to foster its rise as an active contributor to global security, stability and prosperity while also sustaining and securing American leadership in a changing world...This is uncharted territory. And we have to get it right, because so much depends on it" (Quoted in Chris Elder, Robert Ayson, 2012). Therefore, the US does not want to create chances for China to become a super power and replace its sole dominance whereas China always thinks that the US and other states want to slow down its development. As Aaron 
Friedberg argues, recognizing the growing threat to its position, a dominant power (or coalition of status quo powers) may attempt to use force preventively to destroy a rising state before it can achieve its full potential (Friedberg, Autumn, 2005). In contrast to this prediction, however, I argue that the US will not withdraw from this region but also not use force to deal with China in coming years. Instead of doing so, the US will move to contain China's threat (White, 2012 and Mearsheimer J. J., 2001) by the policy of alignment with India, an increasing power in the region, to balance with China as it has tried to do over the past years.

Hence, if India accepts this strategy of the US (which also means India will become an ally of the US), China will face the combined strength of "an eagle and an elephant" (Virmani, 2005). In response to this alignment, China might choose to take actions causing instability for the region. This estimate is based on the characteristics of China, a state with increasing nationalism (Shambaugh, Winter 2011, p. 22). Realists in international relations, who are the dominant group in China and China's global role today, (if not forever) urges China use its newly-built military, economic, and diplomatic influence to essentially coerce others toward the ends China desires. Offensive realists believe that power is worth little if it is not used while defensive realists argue that China should possess strong military might, but should "keep its powder dry" and use it essentially to deter aggression and Taiwanese interdependence (Shambaugh, Winter 2011, p. 12). More particularly, China has become more confident and proud of its economic reform and overall development, its so-called Beijing Consensus (Grant, 2010) over the past decades. Therefore, in the Chinese mind, the West should be aware of its 
remarkable economic success and should consider applying the Beijing Consensus rather than the Washington one.

China may feel constrained and beset by the idea that the alignment of the US and India creates the counter-balancing of China. Not surprisingly, Beijing views the increasing U.S- India partnership as evidence of a growing attempt to contain China's rise. The reconciliation of China towards India was reflected in China's recognition of Sikkim as part of India and the establishment of direct air links between 2002 and 2004 (Indian Express, 2004). However, before the improvement in Indo-US relations after 2005, China responded with negative actions such as blocking India's EAS membership and reasserting its claim on Arunachal Pradesh (Jo Johnson and Richard McGregor, 2007). In 2009, China continuously complained to New Delhi about the visits of the Indian Prime Minister Manmohan Singh, and the Dalai Lama, the Tibetans' spiritual leader to Arunachal Pradesh. Furthermore, China delayed Asian Development Bank loans to India because some of them would go to Arunachal Pradesh, and it also tried to delay World Bank loans (Grant, 2010, p. 2). Consequently, if the US and India align with each other, Asia's future might be more unstable due to critical responses and even overconfidence to affirm Chinese nationalism and strength in the foreseeable future.

\section{India and China: Cooperation and Coexistence}

The second striking consideration however might be that despite the US' efforts to turn an alignment policy with India into reality, India will not heavily rely on the US due to India's traditional autonomy and independence; and its own economic development and security demands. 
Apart from these factors, increasing ties between China and India also contribute to a partly stable and peaceful environment in Asia.

First of all, history has witnessed India's very high levels of autonomy and interdependence. This view was also expressed through the wish of Asian unity and solidarity reflected in the foreign policy of India and newly liberated countries in Asia after the end of the Second World War (Mohan, 2011). Unfortunately, this Asian unity aspiration was not successful and India had to move to a non-alignment policy. Besides this characteristic, India looked to be supported by other great powers such as the US to keep the balance of power with other states that reflected its autonomy and interdependence. According to Mohan, these events reflect Asian countries' features in general and India in particular. Facing obstacles from the outside, they tend to favour a balance of power, and as they become stronger, they might emphasize their own independent role more than accept subordinate positions to other great powers (Mohan, 2011). Thus, if India becomes bigger, this state might not accept the alignment policy and depend on the US. If this is correct, the alignment favoring conflicts and wars in the multipolar model will be less likely to operate as realists argue.

Secondly India also has a complex relationship with China. Both states "share a range of interests and challenges which may, over time, serve as a foundation for greater cooperation, compromise and policy alignment" (Rory Medcalf; Ashley Townshend, 2010, p. 3). Despite territorial disputes, in reality, Indian and Chinese strategic policy aims at the maintenance of a stable international environment to support long-term economic development and both have increased trade and security cooperation and global governance share over the past decades. In 2008, China overtook the United States to become India's largest trading partner. The two states set a bilateral 
trade target of U.S. $\$ 100$ billion by 2015 (Toàn cảnh thế giới, VTV1, 26.5.2013, http://www.youtube.com/watch?v=1gJhleyI3Gk). So in the short term India will pursue a two-pronged strategy trying to avoid a serious confrontation with China and developing a set of alliances and relationships that will reduce the potential threat from China. As in the words of one Indian government official: "The best response to the rise of China is the rise of India” (Grant, 2010).

In sum, Indians do not want to be part of an American strategy for containing China, and parts of the intelligentsia remain instinctively anti-American. But most of the political elite see the link with the US as an important insurance policy against China (Grant, 2010).

\section{The US-India-China triangle: Unpredictable conflicts due to security dilemmas}

However, it is still possible that in the case of a more aggressive China, India might not stay calm forever. The economic interdependence between two giants might be insufficient to ensure the avoidance of conflict or war between India and China. Rehman argues that "the idea of trade being conductive to peace is an old one" which may be "doomed to failure on several counts" (Rehman, 2009, p. 115). In reality, both countries have made surface improvements but deep-rooted conflicts remain. Sino-Indian relations are thus still potentially prone to conflict, despite all efforts at normalization.

First of all, the relations between two states still remain characterised by mistrust and misunderstanding. As for China, the likelihood of going to war with India is contained by concerns related to an Indo-US alliance. China perceives that the alignment between India and the US will be a threat 
towards her security (Rory Medcalf; Ashley Townshend, 2010). Hence, China will be wary of any actions and decisions in Washington and India's partnership with the US. Similarly, there is an Indian concern that if China wants to improve Sino-Indian relations, she must stop supporting Pakistan (Rory Medcalf; Ashley Townshend, 2010, p. 21). India suspects China's military and financial support for Pakistan, which is a rival of India, is designed to project Chinese power and counter India in South Asia (Rehman, 2009, p. 117). In order to counter-contain an Indo-US alignment, China has promoted its relations with India's neighbors, especially Pakistan. More importantly, China has become the most reliable economic partner and arms supplier to Islamabad over many years. It actively assisted Pakistan with its nuclear program form the late 1980s towards. Furthermore, China developed infrastructure projects in Pakistan, Burma, Sri Lanka. The most important of these was the construction of a deep-sea port in Gwardar in Pakistan (Rehman, 2009, p. 118). In sum, although China always denies increasing ties in relations between China and Pakistan, for India "Pakistan is not and cannot be a threat without China's support just as Taiwan cannot constitute a threat to China without America's support" (Mohan Malik, "India and China," p.135) and China's relationship with Pakistan is therefore defined by "far more...than just a common hostility towards India" (Quoted by Rehman, 2009, p.119).

The mistrust and misunderstanding here are increased by the longunresolved territorial disputes over Arunachal Pradesh and Aksai Chin (Rory Medcalf; Ashley Townshend, 2010). Thus, not surprisingly, both states have sought to exclude other's presence in EAS, IONS, Kunming Initiative or the MeKong-Ganga Cooperation Project or MGC to diminish each other's reputation and influence in regional and international forums and 
organizations. China wants to take advantage of Pakistan as a threat to India's rise in South Asia, and India entered into an Indo-US strategic partnership and pursued a Look East Policy leading to skepticism by China. The evidence shows that China "has engaged in a policy of containment of India" and India might not align with the US against China but it might choose to "back its policy of engagement of Beijing with a form of countercontainment” (Rehman, 2009, p. 114). Actually, Ch'ien-peng Chung also argues that "even if the territorial dispute were resolved, India and China would still retain a competitive relationship in the Asia-Pacific region, being as they are, two Asiatic giants aspiring to Great Power status" (Quoted in Scott, 2008, p.263). Consequently, facing this mistrust and misunderstanding as well as their own ambitions, both states might adopt uncontrolled actions or behaviors causing negative responses from the other side that might lead to the escalation of war, or at least continuing conflicts on the borders of these two giants in Asia.

In summary, great power wars seem less likely and might be prevented in terms of alignment between major states (the balance of power). Nevertheless, there are likely to remain potential conflicts between great powers if we consider the situation in other approaches. For example, China's war against Vietnam or Indonesia's violent 1975 annexation of East Timor can give other answers on stability and instability from avoidance of armed violence of these conflicts (Robert Ayson, p. 196, 2005). Therefore, we need to examine the other factor (the stability of distribution of power) to check whether a more multipolar Asia will be stable or not. 


\section{The stability of the distribution of power}

The distribution of power is at the core of realism which refers to the balance of power and the struggle for survival, and the national interests of states in anarchical systems (Mearsheimer, 2008 and Jackson, R., Sorense, G., 2001). In order to examine this element, I will examine two factors including (1) the checks and balances between major states and (2) the legitimacy of major powers.

\section{The checks and balances between major states}

First of all, the stability of the Asian distribution of power is mainly affected by China's and India's re-emergence as great players. On the one hand, from its sole super power and hegemon status since the Cold War, the US role has changed in part on the international and regional stage due to the role of these emerging states. In the context of China's rise, the US is often considered as an extra-balancer in Asia by America's own view itself and by the approach of other states such as the Southeast Asia countries towards China's rise. With its presence in the region, the US can check and prevent China from becoming a regional hegemon, a point that is explained by its three goals in Asia including "prevent the rise of a regional hegemon, maintain stability and manage Asia's transformation" (The United States and Asia: Toward a New U.S. Strategy and Force Posture, 2001).

Faced with China's rise in terms of rapidly a increasing economy and expanded military, in tandem with its relative decline, the US cannot force 
China to give up her aspiration to dominate Asia, so the US has to have a smarter option that means it should retain its presence in Asia to maintain its role and constrain China's influence in the region (White, 2012). At least, the US presence in Asia might help to avoid chaos caused by regional great power competition and encourage China to be reserved in exercising its regional and global aspirations (White, 2012 and Hillary Clinton, 2011).

Although the US always denies its pivot strategy is aimed at the containment of China, its actions and behaviors in Asia are clearly designed to cope with China's rise. In order to rebalance China's rise, the Obama Administration announced that the Asia-Pacific region was a "top priority" of US security policy encompassing a plan that by 2020 about $60 \%$ the US fleet would be deployed in the region (Leon Panetta: US to deploy 60\% of navy fleet to Pacific, BBC news, June 2th 2012). Furthermore, the US is renewing and strengthening traditional alliances and simultaneously establishing new strategic partners with states in Asia (Goh, Winter 2007-2008). The US has enhanced exercises with Japan, Singapore, the Philippines, Vietnam and even Myanmar. In Southeast Asia, the US entered the Treaty of Amity and Cooperation (TAC), which China reached in 2003, with ASEAN in Thailand in 2009. By acceding to the TAC, the US was accepted by ASEAN to join the East Asia Summit and to participate in the ASEAN Defense Ministers Meeting aming at resolving regional issues. The speech of Defense Secretary Chuck Hagel at the 12th International Institute for Strategic Studies (IISS) Asia Security Summit: The Shangri-La Dialogue, in Singapore June 1, 2013 recently reaffirmed "the US' pivot in Asia despite budget constraints at home noting the United States represented 40 percent of global defense spending even under the "most extreme budget scenarios" and assured allies and partners that "It would be unwise and short-sighted to conclude ... that our 
commitment to the rebalance cannot be sustained" (US rebalance to AsiaPacific gaining steam, Pentagon chief says, Reuters, June $1^{\text {st }}$, 2013).

In particular the US has tried to ally with India to counter-contain China to reduce China's influence in Asia (Mohan, 2006). In the past, the US imposed sanctions on India due to its nuclear program. However as India becomes a nuclear power in the region, the US started to side with India marked by a nuclear cooperation deal in 2005 that upset China and Pakistan (Grant, 2010 and Rehman, 2009). In US strategy, the US will help India to reduce the economic and technological gap between India and China which helps India become a stronger pole in Asia, and keep a balance with China (Virmani, 2005 and Mohan, 2006). Rehman also asserts that "India has thus required a new importance as a counterweight to China in the Asian theater, providing the triangular relationship between the US, China, and India with a form of strategic salience it never had in the past" (Rehman, 2009, p. 126). The above actions show that the US wants to ally with states in the region to contain China's military power and express its willingness to translate a potential alliance with India into reality.

For China, a stable distribution of power means that the world in general and Asia in particular should be a multipolar system and China's role in international and regional stages should be recognized that it will advocate the peace and the stability in the long term (Ayson, 2005, p. 198). Power balancing in the Chinese view favors the idea that it should not support US' hegemony as over the past decades. That is why Chinese Premier Wen Jiabao said at a meeting with visiting U.S. President Barack Obama that "China pursues the independent foreign policy of peace and will not align with any country or country blocks and global issues should decided by all 
nations in the world, rather than one or two countries" (Chinadaily.com.cn, 11.18.2009). Then, given this assumption, the stable distribution of power will involve a transition in the regional system from unipolarity to multipolarity. As a result, on one hand, China has enhanced relations with India. On the other hand, China has not stopped supporting Pakistan with military weapons and finance, a main rival of India, to counter the likelihood of the US-India alliances. As Rehman argues, "Beijing's efforts to assist Pakistan as a peer competition to India in South Asia show that despite certain improvement in Sino-Indian relations, Beijing remains subject to realist balance-of-power considerations in its dealings with its neighbor" (Rehman, 2009, p. 119).

India has become an important swing player in the evolving international system and in its dealings with both China and the US (Mohan, 2006; Scott, 2008, p. 263 and Rehman, 2009). Among three major powers, it seems that India has the most abilities to align or tilt any other significant powers against or counter another competitor to benefit. That is why India started to have good relations with the US as the US declared India "a major nonNATO ally" and the highest point of the warmth of Indo-US ties was a landmark nuclear deal ${ }^{5}$. Furthermore, India has implemented the Look East policy with extended-neighbor states to improve the balance of power with

\footnotetext{
5 To understand India's increased rapprochement with the US, see Rehman, India's counterContainment of China in Asia, 2009. For example, when George W. Bush came to power, India offered the US the use of its airfields in its strike against Afghanistan and allegedly provided intelligence which led to the destruction of several al-Qaeda training camps in Afghanistan and especially the highest point in a landmark nuclear deal. Both countries signed a framework defense agreement in June 2005 on a ten-year program of increased defense cooperation. The US offered to supply the Indian Air Force with F-16s and F-18s and allowed Israel to sell India three Phalcon AWACs or Airborne Warning Aircraft whilst it refused to do in the case of China. India and the US have held military exercises.
} 
China's threat (Rehman, 2009, p. 127) and there are also signs of Southeast Asian countries welcoming India as a counter weight to China's influence (Acharya, 2003/2004).

Despite such a countermove, the evolution of Sino-India ties has been promoted over the past decade. In April 2005, India and China announced a "strategic partnership" (Mohan, 2006, p. 21). Consequently, China is likely to be prepared to make some concessions to India, and try to get India to instead balance with itself against US preeminence in the international system (Scott, 2008, p. 263). However, the problem is that it is uncertain whether India will become the US's "Asian Israel" due to the tradition of a fiercely independent foreign policy (Rehman, 2009, p. 129). At that time, Mohan argued that this approach might misunderstand India's non-alignment policy as well as the nature of India's realpolitik over the past 60 years, because India has not had difficulty entering into alliances when its interests so demand (Mohan, 2006, p.25).

In fact, although denying encirclement as characterizing their own policies, both India and China have used other types of power balancing including socalled soft balancing and internal balancing to deal with each other (Scott, 2008, p. 243-248). India does not want to follow the US' strategy explicitly and China cannot encircle India completely, but both states established good relations with other states who are rivals of the other one to balance with each other. For example, India has had ongoing good relations with the US and Southeast Asian states and China has had good relations with Pakistan and India's neighbors. 
Clearly the US and China, and also India, have different definitions of stability in the region. Thus, will the shift from the existing distribution of power into a new one satisfy all states in the system or not? Or in other words, does this shift ensure checks and balances between major states to avoid armed conflicts or hegemony? Actually, the US will rely on India and Southeast Asian countries to develop a counter-balance of China. The Southeast Asian countries have shown signs of welcoming the US and India's presence in the region to balance China. For its part, China has established relations with India's neighbors such as Pakistan and maintained the relations with North Korea to counter with India and the US. In reality, India also might not travel alone in the road of shaping the new order in Asia to affirm its great power status. Hence, the check and balance of power in the region seems to be equally retained in calculations of major states in the context of a more multipolar Asia. However, these two "check and balance of power" factors are insufficient to allow a conclusion of whether the more multipolar Asia might result in a stable system or not. In India-China relations, it still remains a question as to how much they can accept each other to ensure their legitimacy in each other's eyes that partly helps them respect and reduce competition with each other. Or in other words, the stability of Asia therefore depends on the legitimacy of major powers.

\section{Legitimacy of major powers}

Explaining the tendency of inter-state war reduction in Asia over the past decades, Multhiah Alagappa argues that an increase in legitimacy of nations and states along with growing state capacity are elements contributing to the transition and strengthening of peace (Alagappa, 2011). Accordingly, "legitimacy has international and internal dimensions. External legitimacy is 
constituted by recognition of sovereignty, identity and territorial boundaries" (Ibid p. 16). In light of this idea, I argue that under the multipolar model dominated by the US, China and India there are some problems relating to the legitimacy of major states. The US might have been the sole superpower accepted by the two other powers due to its economic, military and soft power capabilities and especially its long-established dominant role after the Cold War. However, issues exist with China and India's legitimacy.

First of all, China has met obstacles and objections from India, emerging states and China's neighbors involved in territorial disputes. Despite efforts to resolve territorial disputes over recent decades, China has not resolved its main disputes over Taiwan, Tibet, Aranuchal and maritime territorial disputes over Senkaku/Diafao and the South China Sea. China's South China Sea claims consists of 80 percent of sea sovereignty (Vietnam, China seek peaceful, stable solutions to sea dispute, thanhniennews, 2013) and has caused critical responses from related states, expressed in a symbolic case that Manila decided to bring the maritime dispute to the International Tribunal on the Law of the Sea to object China's aggressive and illegal actions in this state's sea area (Philippines to bring Scarborough Shoal row to international court, InqirerGlobalNation, $14^{\text {th }}$ June, 2013). In recent times, China troops set up a camp far inside a region claimed by India. Nevertheless, after New Delhi threatened to cancel the visit by 2-3 officials to China and both sides reached an agreement for a joint pullback, the Army began to withdraw (India, China began withdrawing troops from borders, 2013 and Binh, 2013). Meanwhile, according to most international legal experts, the claims of China based on "China's historical territory since ancient times" are invalid because there are several contradictions in China's use of history to justify its claims to islands and reefs in the South China Sea, 
and "ought to be resolved through a combination of customary international law, adjusdication before the International court of Justice or the International Tribunal for the Law of the Sea, or arbitration under Annex VII of the United Nations Convention on the Law of the Sea (UNCLOS)." (Malik, 2013). Furthermore, Malik argues that official Chinese history claiming that Mongols, Tibetans, Manchus, and Hans were all Chinese, distorts the complex history. Actually, most Southeast Asian countries cannot accept China's nine-dash line for "a corresponding denial of the very identity and history of the ancestors of the Vietnamese, Filipinos, and Malays; it is practically a modern revival of China's denigration of nonChinese as 'barbarians' not entitled to equal respect and dignity as peoples." (Jay Batongbacal of the University of the Philippines law school, quoted in Malik, 2013).

Secondly, India might accept the leading role of China in shaping Asia's geopolitical future and considers itself as a peer competitor of China in the US-China- India triangle (Chris Elder, Robert Ayson, 2012 and Scott, 2008) but will China accept India's rise?. In 2006, Kondapalli put a question "the issue is that China has never recognized India...as a major power. China will never accept the rise of another power in Asia" like India (quoted in Anejia and Kumar, "Tibet, connectivity, Capabilities and Consequences," p.45). Roy also agrees with this view and argues as follows, "China would like India to remain locked in South Asia...India has always been seen by Beijing as the main stumbling block to a unipolar Asia dominated by China" (quoted in Scott, 2008, p. 262).

China has been the main increasing power globally and its increasing international clout makes it more confident in its capacity and in pursuing the 
aspiration which is being the most important candidate for the regional dominance. China must not have accepted India as a Great Power and supported India to become the leading role in the region due to the potential competition of India. In practice, China tried to exclude India in the ASEM (Asia-Europe Summit), the APEC (Asia-Pacific Economic Cooperation), the EAS (East Annual Summit), the SCO (Shanghai Cooperation Organization) and especially the UNSC (the United Nations Security Council) (Rory Medcalf; Ashley Townshend, 2010; Scott, 2008). The purpose of China is to maximize Indian influence in the forums and reduce India's increasing clout in the global and international stage. It is right as one analyst said "One mountain cannot accommodate two tigers" (Mohan Malik J., 1999) to describe the China- India relations.

Thus, if we agree with the view that China's legitimacy remains the problem and if China cannot accept India's legitimacy, the stability of Asia clearly depends on capabilities of states to "govern effectively, manage international interaction, and resist external aggression" (Alagappa, 2011, p. 16). It is because that state's capacity along with legitimacy will help it to be able to cope with domestic and international conflict. If the index of a state's legitimacy is not high, the existence as well as influence of the state depends on the abilities to manage or resolve issues caused by objections of other states in the system or in the government. As shown by Alagappa, this assumption was evidence to the stability of the Asian map since 1945 (Alagappa, 2011). 


\section{CONCLUSION}

As showed in this thesis, multipolarity and stability have a close relationship with each other. However, the stability here is considered not only as war avoidance among the great powers but also as the tendency of equilibrium of the system. So measuring the stability in Asia requires examining at least two factors including war avoidance among the great powers and the stability of distribution of power. This research finds that Asia will be more multipolar, with more likely the leading dominance of the US, China and India, at least in next twenty or thirty years. In theory and reality, the more states there are in the system, the more tension and competition and the more likely conflicts become. However, in Asia multipolarity lessens the likelihood of great power wars due to states' increasing economic interdependence and the security requirements of themselves as states, means that these states "will not wish to court disaster" and will try to resolve issues without war (Posen, 2009). Another factor contributing to this outcome is India's traditional autonomy and independence that makes the theory of allying between states not probable in this case. Nevertheless, as we examine the distribution of power in this pattern, two elements including a "check and balance" between great powers in the region seems to be sustained, whereas, on the other hand, there are still some problems in states' legitimacy.

Despite its efforts in resolving territorial disputes and exercising a "charm offensive" and some states are more willing to accept China, China's legitimacy has still not been accepted by some other states, especially Southeast Asian countries, due to China's aggressive behaviour and ambitions. In addition, the relationship between China and India raises an 
open question over how far China can accept India's legitimacy. These issues might create more mistrust and misunderstanding between India and China and allow potential conflicts or even war in the future. Actually, despite such suspicions, I still hope that in context of a more multipolar Asia, states will try to avoid unnecessary conflicts to ensure the region's stability and prosperity in general, and each state in particular. This partly is the outcome of India's swing state's role and responsibility of taking into consideration its foreign policies towards the US and China.

In sum, cooperation and competition for power is the main tendency that is likely to persist in Asian multipolarity. Of course, this is not only an outcome of the structure of the system but also due to other factors relating to states' perception and understanding. Therefore, in relation of three dyads, the US must avoid unilateralism but should not withdraw from the region due to its economic interests and the region's stability. Instead, the US should retain its role in Asia, enhance engagement and deepen its commitment into regional actions. However, the US should not develop behavior or actions which increase China's mistrust and misunderstanding, including issues relating to Taiwan. As for China, its efforts to become the sole regional dominant power in Asia should be limited because China's aggressive behavior and ambition might cause negative actions and responses from India. In contrast to this, as this thesis has shown, certain countries in Southeast Asia such as Vietnam need India as a way of countering Chinese influence in the region. Furthermore, the US considers India as a counter-balance with China. It might remain an open question whether the alliance between the US and India will undermine the process of Sino-Indian normalization and cause the instability in the region. As a result, in order to make the situation more 
stable, India should be wise and clever in dealing with China and the US, avoiding an increase in historical mistrust and misunderstanding.

Finally, as showed in chapter one, this thesis presents the writer's ideas based on defining stability in terms of the tendency to equilibrium. In order to achieve better outcomes in measuring stability of Asia multipolarity, we should think of the stability of economic cooperation between states and the outcomes of building norms and institutions in the region. These factors have the ability to reflect the existence and persistence of stability in the region in theory and reality. We should not ignore them as a way of measuring the stability of the region under different circumstances.

\section{Bibliography}

10 quân đội hùng mạnh nhất thế giới. (2013). Thanhnien.com. Retrieved from: http://www.thanhnien.com.vn/pages/20130618/10-quan-doi-hung-manh-nhatthe-gioi.aspx .

A.Pape, R. (2009). Empire Falls. The National Interest, 99.

Acharya, A. (2012, May). China's rise and security in the Asian century. East Asia Forum .

Acharya, A. (2003/2004). Will Asia's Past Be Its Future? International Security, 28 (3), 149-164.

AFP. (2008, November 4). EU estimates eurozone recession slump. The Sydney Morning Herald. Retrieved from: http://news.smh.com.au/breaking-newsbusiness/eu-estimates-eurozone-recession-slump-20081104-5h5k.html.

Alagappa, M. (December 2011). A Changing Asia: Prospects for War, Peace, Cooperation, and Order. Political Science, 63 (2), 155-185.

Alagappa, M. (2011). A changing Asia-Pacific: Prospects for war, peace, cooperation and other. Discussion Paper, 9 (11), 1-35.

An do tang suc mang quan su doi pho voi Trung Quoc. (2013). kienthuc.net.vn. Retrieved from: http://kienthuc.net.vn/binh-luan/201304/an-do-tang-suc-manhquan-su-kiem-che-TQ-903187/ .

An, T. (13/5/2013). Bao giờ Trung Quốc theo kịp Mỹ về quân sự? (When will China's military catch up the US'). Vietnamnet. Retrieved from: 
http://dantri.com.vn/the-gioi/bao-gio-trung-quoc-theo-kip-my-ve-quan-su729933.htm .

Anh, D. T. (2011). An Do cuong quoc moi doi trong voi Trung Quoc o Chau A. Nghien cuu Bien Dong.vn .

Asean nations fail to reach agreement on South China Sea. (2012). BBC News. Retrieved from: http://www.bbc.co.uk/news/world-asia-18825148 .

Athukorala, P.-C. (2009). The rise of China and East Asian export performance: Is the Crowding-out fear warranted? The world economy .

Aubin, D. (2013, May 8). U.S. companies' overseas earnings hit record \$1.9 trillion: study. Reuters. Retrieved from: http://news.yahoo.com/u-companies-overseasearnings-hit-record-1-9-185750919.html.

(October 2012). Australia in the Asian Century. In Chapter 8: Building sustainable security. Australian Government (White Page). Retrieved from: http://asiancentury.dpmc.gov.au/.

Ayson, R. (2005). Regional Stability in the Asia-Pacific: Towards a Conceptual Understanding. Asian Security, 190-213.

Barbieri, K. (February 1996). Economic Interdependence: A Path to Peace or a Source of Interstate Conflict? Journal of Peace Research, 33 (1), 29-49.

Barboza, D. (2010, August). China Passes Japan as Second-Largest Economy. The New York Times .

Beckley, M. (2011). China's century? Why America's Edge will endure. International Security, 36 (3), 41-78.

Before talks, a CBM: China puts Sikkim in its India map . (2004). The Indian Express .

Berger, T. (July 2000). Set for Stability. Review of International Studies , 26 (03), 405-428.

Betts, R. K. (Winter, 1993-1994). Wealth, Power, and Instability: East Asia and the United States after the Cold War. International Security , 18 (03), 34-77.

Bhat, P. M. (2001). Demographic scenario, 2025.

Binh, D. (2013, June 10). Báo Ân Độ: Sự kiện đối đầu biên giới Trung-Ấn gần đi vào đường cùng . Vietnam: http://giaoduc.net.vn/Giao-duc-Quoc-phong/BaoAn-Do-Su-kien-doi-dau-bien-gioi-TrungAn-gan-di-vao-duong-cung/300874.gd.

Bitzinger, R. A. (2010). A new arms race? Explaining recent Southeast Asian Military Acquisitions. Contemporary Southeast Asia , 32 (1), 50-69.

Bitzinger, R. A. (2011). Chapter two: Recent Developments in Naval and Maritime Modernization in the Asia-Pacific: Implications for Regional Security. In The Chinese Navy: Expanding Capabilities, Evolving Roles? (pp. 1-222). Institute for National Strategic Studies (INSS), Washington DC, United States.

Bloom, D. E. (January/2011). Population Dynamics in India and Implicatons for Economic Growth.

Bower, E. (2010). Chiến lược của Mỹ với ASEAN. BienDong.net. Retrieved from: http://www.biendong.net/binh-luan/124-chien-luoc-cua-my-voi-asean.html .

Bremmer Ian and Evan A. Feigenbaum. (2011). Why US-China economic competition will grow. Finance and Economy. 
Breslin, S. (2011). China and the crisis: global power, domestic caution and locao initiative. Comtemporary Politics , 17 (2), 185-200.

Brewster, D. ((Spring 2010)). An Indian Sphere of Influence in the Indian Ocean? Security Challenges , 6 (3), 1-20.

Chang, G. G. (2012). Will China have the World's largest economy by 2030? World Affairs .

Chapter II: The Effects of the Atomic Bombings. (1946). The effects of Atomic Bombs on Hiroshima and Nagasaki. Washington, The United States, The United States:

http://www.ibiblio.org/hyperwar/AAF/USSBS/AtomicEffects/AtomicEffects2.html.

(October 2012). Chapter two: The Future of Asia to 2015. In Australian in the Asian Century. Australian Government.

Chiến, N. (2012). Sự suy thoái kinh tế gia tăng ở Nhật Bản. Baodientuchinhphu.vn. Retrieved from: http://baodientu.chinhphu.vn/Home/Suy-thoai-kinh-te-gia-tango-Nhat-Ban/201212/156082.vgp .

Chin, Gregory;Helleiner, Eric. (2008). China as a creditor: a rising financila power? Journal of International Affairs , 62 (1), ProQuest Central pg. 87 .

China End-2007 Net Foreign Financial Assets Up to 67 Percent. (2008, 20 June). Reuters.

China maps path to new conflicts in its passports. (2012). The Sydney Morning Herald. Retrieved from: http://www.smh.com.au/world/china-maps-path-tonew-conflicts-in-its-passports-20121123-29x7m.html .

China raising 2012 Defense Spending to Cope With Unfriendly 'Neighborhood'. (2012). Bloomberg.com. Retrieved from: http://www.bloomberg.com/news/2012-03-04/china-says-defense-spendingwill-increase-11-2-to-106-4-billion-in-2012.html .

(2000). China's National Defense in 2000. Information Office of the State Council of the People Republic of China .

China's Peaceful Rise: Speeches of Zheng Bijian 1997-2005. (2005). Brookings Institution Press.

Choi, W. (2010-11-11 ). The Stability of the Balanced Multipolarity in Future Asia.

Christense Thomas J.; Jack Snyder. (1990). Predicting Alliance Patterns. International Organization, 44 (2).

Clinton, H. (November 2011). America's Pacific Century: The Future of Geopolitics Will Be Decided in Asia, Not in Afghanistan or Iraq, and the United States Should Be Right at the Center of the Action. Foreign Policy, 56-63.

Cooper, R. (2013). China "to overtake America by 2016". The Telegraph .

Daalder Ivo H. and James G. Stavridis. (March/April 2012). NATO's victory in Libya - the right way to run an intervention. Foreign Affairs .

Demetriou, D. (2013). Japan's population suffers biggest fall in history. The Telegraph .

Deutsch Karl W., Singer David J. . (1964). Multipoalar power systems and international stability. World Politics , 16 (3), 390-406. 
Dholakia, B. H. (2001). Sources of India's accelerated growth and the vision of Indian economy in 2020. Indian Economic Journal, 49 (4).

Dobbins, J. (2012). War with China. Survival: Global politics and Strategy , 54 (4), 7-24.

Doug Bereuter and John J. Brandon. (2008). America's role in Asia: Asian and American views. U.S.A: The Asia Foundation.

Dougherty, N. D. (2008, October 6). A United Image, Battered by Reality. The NewYork Times. Retrieved from: http://www.nytimes.com/2008/10/07/business/07euro.html?fta=y\&_r=0) .

Elder Chris, Robert Ayson. (2012). China's rise and New Zealand's interests: A policy prime for 2030 (Vol. 11). Wellington, New Zealand: Centre for Strategic Studies: New Zealand Victoria University of Wellngton.

Fackler, M. (2012). China threat spurs Japan to expand military presence. The Sydney Morning Herald.

Fackler, M. (2008, October 23). Financial Crisis Spreads to Emerging Nations. NewYork Times. Retrieved from: http://www.nytimes.com/2008/10/24/business/worldbusiness/24won.html?adxn $\mathrm{nl}=1 \& \mathrm{adxnnl} \mathrm{x}=1375319129-\mathrm{zFv}+\mathrm{Fl} 4 \mathrm{D} 2 \mathrm{BtD} 8 \mathrm{x}+5 \mathrm{UCAKDw}$.

Finally, Pranab Calls China a Challenge. (November 5, 2008). Times of India .

Foot, R. (2006). Chinese Strategies in a US-hegemonic Global Order:

Accommodating and Hedging. International Affairs , 82 (1).

Fravel, M. T. (December 2011). China's Strategy in the South China Sea. Contemporary Southeast Asia , 33 (3), 293-319.

Friedberg, A. L. (Winter, 1993-1994). Ripe for Rivalry: Prospects for Peace in a Multipolar Asia. International Security, 18 (3), 5-33.

Friedberg, A. L. (Autumn, 2005). The Future of U.S.-China Relations Is Conflict Inevitable? International Security, 30 (2), 7-45.

Friedberg, A. (2000a). Will Europe's Past be Asia's future. The International Institute for Strategic Studies , 42 (2), 147-59.

Friedberg, L. A. (2000b). The Struggle for Mastery in Asia. Commentary, 110 (4), 17-26.

Friedman George, Meredith Lebard. (1991). The coming war with Japan. New York: St. Martin's.

(2012). GDP growth (annual \%). The World Bank.

(2012). Global trends 2030: Alternative Worlds. The National Intelligence Council. GlobalChinatrade.com. (2013). How economies grow? Global China trade.com .

Goh, E. (Winter 2007-2008). Great Powers and Hierarchical Order in Southeast Asia: Analyzing Regional Security Strategies. International Security, 32 (03), 113-157.

Goldsmith, B. (January 2007). A Liberal Peace in Asia? Journal of Peace Research , 44 (1), 5-27.

Grant, C. (2010). India's response to China's rise. London: Centre for European Reform.

Heng, P. (2012). Cambodia-China relations: a positive-sum game? Journal of current Southeast Asian Affairs , 31 (2), 57-85. 
Hesketh, T. and Lu, L. and Xing, Z.W. (2005). The effect of China's one-child family policy after 25 years. New England Journal of Medicine , 353 (11), 1171-1176.

Hien tai va tuong lai cua quan he Trung My. (2012). Nghien cuu Bien Dong.vn. Retrieved from: http://nghiencuubiendong.vn/quan-h-quc-t/3141-hien-tai-vatuong-lai-cua-quan-he-trung-my .

Hong Kong falls into recession: government. (2008, November 15). The China Post Retrieved from: http://www.chinapost.com.tw/business/asia/hongkong/2008/11/15/183373/Hong-Kong.htm.

$\mathrm{Hu}$, S. (2012). China's Gini Index at 0.61, University Report Says. Caixin Online . Hughes, C. W. (1997). Taiwan and Chineses Nationalism: National Identity and Status in International Society. New York: Routledge.

Hughes, C. W. (2006). Why Japan can revise its Constitution and What it would mean for Japanese Security Policy. Based on author's presentation at a conference on Constitutional Change and Foreign Policy in East Asia , 1-19.

(2010). Human Security Report 2009/2010: The Causes of Peace and The Shrinking Costs of War, 2010, p.45. Human Security Report Projet.

Hung Ming-Te and Tony Tai-Ting Liu. (2011). Sino-U.S. Strategic Competition in Southeast Asia: China's Rise and U.S. Foreign Policy Transformation since 9/11. Political Perspectives , 5 (3), 96-119.

Huntington, S. P. (Winter 1988). The U.S. - Decline or Renewal? Foreign Affairs (89).

India and China quarrel over their maps on passport and visa stamps. (2012). The Washington Post .

India as a great power. (2013). Economist.com .

India challenges China in South China Sea. (2000). Asian Times.com .

India probably world's 3rd largest economy, ahead of Japan: OECD. (2013). The

Indian express. Retrieved from:

http://articles.economictimes.indiatimes.com/2013-05-

30/news/39603030_1_gdp-growth-third-largest-economy-economic-growthprojection .

India probably world's 3rd largest economy: OECD. (2013). The Economic Times .

India, China began withdrawing troops from borders. (2013, May 6). Retrieved from: http://tribune.com.pk/story/545070/india-china-begin-withdrawingtroops-from-border/.

India's claim in South China Sea further polarises rows. (2012). South China Morning Post .

India's econom: India's surprising economic miracle. (2010). The Economists . Jackson, R. , Sorense, G. (2001). Introduction to International Relations. New York:, The United States: Oxford University Press).

Japan: Amendment of Constitution, Article 9. (2006, February).

Jervis, R. ( 1978, Jan). Cooperation Under the Security Dilemma. World Politics, $167-214$.

Jisi, W. (March/April 2011). China's Search for a Grand Strategy: A Rising Great Power Finds its Way. Foreign Affairs, 90 (02), 68-79. 
Jisi, W. (2010). The China-Japan-US Triangle: A Power Balance Analysis. In G. Curtis, R. Kokubun, \& W. Jisi, Getting The Triangle Straight, Managing China-JaPan-US Relations (pp. 1-298). New York: Japan Center for International Exchange, Inc.

Jo Johnson and Richard McGregor. (2007, June 12). China raises tension in India border dispute. The Financial Times .

Joffe, J. (September/October 2009). The Default Power: the false prophecy of America's decline. Foreign Affairs .

Johnson, C. (2005, March 15). No Longer the "Lone" Superpower. Globalpolicy .

Joseph S. Nye, J. (2008). Public Diplomacy and Soft Power. The ANNALS of the American Academy of Political and Social Science, 616 (94), 94-109.

Kang, D. C. (2003). 'Getting Asia Wrong: The Need for New Analytical Frameworks. International Security, 27 (4), 57-85.

Kenedy, P. (1987). The Rise and Fall of the Great Powers. United States: Random House.

Koh, T. (n.d.). The United States and Southeast Asia. America's role in Asia, 3554.

Koval, A. (2012). China and the USA Started Armament Race. Eroupean Dialouge

Krekel, B. (October 2009). Capability of the People's Republic of China to Conduct Cyber Warfare and Computer Network Exploitation. US-China Economic and Security Review Commission.

Kupchan, C. A. (Autumn, 1998). After Pax Americana: Benign Power, Regional Integration, and the Sources of a Stable Multipolarity International Security. International Security, 23 (2), 40-79.

Ladwig, W. C. (2009). Delhi's Pacific Ambition: Naval Power, "Look East," and India's Emerging Influence in the Asia-Pacific. Asian Security, 5 (2), 87-113.

Lam, P. E. (2007). Japan's quest for "soft power": Attration and Limitation. East Asia , 24, 349-363.

Lampton, D. M. (2001). Same Bed, Different Dreams: Managing U.S.-China Relations 1989-2000. Berkeley : University of California Press.

Launey, G. D. (2012). Has Chinese power driven Asean nations apart? BBC News, Phnom Penh .

Layne, C. (2012). The Global Power shift from West to East.

Leon Panetta: US to deploy $60 \%$ of navy fleet to Pacific. (2012). BBC news.co.uk. Retrieved from: http://www.bbc.co.uk/news/world-us-canada-18305750 .

LineBaugh, S. T. (2013, March 10). More U.S. Profits Parked Abroad, Saving on Taxes. The Wall Street Journal. Retrieved from: http://online.wsj.com/article/SB10001424127887324034804578348131432634 740.html.

Linh, H. (2012). Quan su Nhat Ban manh nhu the nao. Vietnamnet.vn .

Liu, N. (2013). China Sees Threat in US Pivot to Asia. VOAnews.com. Retrieved from: http://www.voanews.com/content/china-sees-threat-in-us-pivot-toasia/1677768.html . 
Lu, H. (2001). U.S. Impact on Asia Is Weakening All the Time. Beijing Renmin Ribao .

Mabasa, R. C. (2012). PH: We'll Take A Stand, With Or Without US.

Malik, M. (n.d.). "India and China", p.135.

Malik, M. (2013, May/June). Historical Fiction: China's South China Sea Claims. World Affairs .

McDougall, D. (2012). Responses to 'Rising China' in the East Asian Region: soft balancing with accommodation. Journal of Contemporary China , 21 (73), 117.

Mearsheime, J. J. (2008). Anarchy and the struggle for power. In J. L. Karen A. Mingst, Essential readings in world politics (3rd ed., pp. 60-79). New York, The US: W.W. Norton \& Company, Inc.

Mearsheimer, J. J. (Summer 1990). Back to the future Instability in Eruope after the Cold War. International Security, 15 (1).

Mearsheimer, J. J. (2001, September/October ). The future of the American Pacifier. Foreign Affairs .

Mearsheimer, J. J. (1990). Why We Will Soon Miss The Cold War. The Atlantic Monthly, 266 (2), 35-50.

Medcalf Rory; Ashley Townshend. (2010). India and China: Competitive Coexistence in the Asian Century. In South Asia in the New Decade:

Challenges and Prospects. Based on a presentation by Rory Medcalf at the 6th International Conference on SouthAsia held by the Institute of SouthAsian Studies, Singapore, on November 11, 2010.

Mohan Malik, J. (1999, May 24). The India-China Divide. The Hindustan Times .

Mohan, C. R. (2011). Great powers and Asia's destiny: A view from Delhi. CSS Discussion Paper, 10, 1-15.

Mohan, C. R. (2006, July/August ). India and the Balance of Power. Foreign Affairs , 17-32.

Mohan, C. R. (2008). India's Geopolitics and Southeast Asian Security. Southeast Asian Affairs , 43-60.

Moulds, J. (2012). China's economy to overtake US in next four years, says OECD. Guardian .

Mulgan, A. G. (October 26th, 2010). US-Japan alliance the big winner from the Senkaku Islands dispute . East Asia Forum. org. Retrieved from: http://www.eastasiaforum.org/2010/10/26/us-japan-alliance-the-big-winnerfrom-the-senkaku-islands-dispute/) .

Mỹ khẳng định tái cam kết bảo vệ Nhật Bản về "ô hạt nhân" (The US reaffirms commiments to Japan on "nuclear shield"). (2013). Vietnamplus.vn .

(2010). National Security Strategy. The White House.

(June 2000). New Zealand's Foreign and Security Policy Challenges. New Zealand Ministry of Foreign Affairs and Trade.

Ngọc, H. B. (2012). Nỗi đau của người Nhật từ vụ ném bom nguyên tử Nagasaki. Baomoi.com . 
Nguyên, H. (2013). Trung Quốc phản ứng trước tuyên bố rắn của Obama về biển Đông (China respones before tough claims on the South China Sea). BaoDatviet online .

Nguyet, M. (2013). Kinh tế Nhật Bản 6 tháng đầu năm 2013. Center for Japanese studies.

Nguyệt, M. (2013). Tổng quan Kinh tế Nhật Bản 2012. Center for Japanese studies.

Nhật Bản công bố sách Trắng An ninh Quốc phòng 2013 (Japan publishes Defense White Paper 2013). (2013). Vietnamplus.vn .

Ninh, K. (n.d.). "Vietnam Struggle and Cooperation," in Alaggapa. Asian Security Practice, 462.

Nizamani, S. (2012). Indian Strategic Thinking Vis-à-Vis Indian Ocean - OpEd. Eurasia Review.com .

North, G. (2011). The Dollars as the World Reserve Currency. LewRockwell.com .

Nye, J. S. (2004). Soft Power and American foreign policy. Political Science Quarterly, 119 (2), 255-270.

Nye, J. S. (2005). Soft Power Matters in Asia. Belfer Center for Science and International Affairs.

Nye, J.S., Wang Jisi. (2009). Hard Decisions on Soft Power. Harvard International Review, October $26^{\text {th }}$, 2009. Retrieved from: http://hir.harvard.edu/agriculture/hard-decisions-on-soft-power.

Oksenberg, M. (1997). Issues on which China and the United States Have Different Perspectives. In A. A. Assembly, \& E. F. Vogel (Ed.), Living with China, USChina Relations in the Twenty-first Century (pp. 9-319). New York: w.w Norton and Company.

O'Rourke, R. (2012). China Naval Modernization: Implications U.S. Navy Capabilities-Background and Issues for Congress. Congressional research service.

Overholt, W. H. (2002). Japan's Economy, at War with Itself. Foreign Affairs , 81 (1), 134-147.

Perlo-Freeman Sam, Elisabeth Sköns, Carina Solmirano and Helén Wilandh. (April 2013). Trends in World military expenditure, 2012. Sweden: SIPRI.

Petras Austrevicius and Jonh Boozman. (2007). The rise of the East-Asian economic system implications for Europe and North America. NATO Parliamentary Assembly .

Philippines to bring Scarborough Shoal row to international court. (2013). Inquirer Global Nation .

Posen, B. R. (2009). Emerging Multipolarity: Why Should We Care? . Current Hístory, 347-352.

Quỳnh, N. (2013). Mỹ khẳng định quan điểm trong vấn đề biển Đông (The US affirm views in the South China sea). VOV online .

Rajan, D. S. (2007). China: Media Fears Over India Becoming Part of Western Alliance . South Asia Analysis Group, 2350.

Record High China-US Trade close to US\$ 500 billion. (2012, December 28). Ministry of Commerce People's Republic of China . 
Rehman, I. (2009). Keep the Dragon at Bay: India's Counter-Containment of China in Asia. Asican Security, 5 (2), 114-143.

Reynolds, I. (2013). Japan Defense Budget to Increase for First Time in 11 Years. Bloomberg.com .

Roberts, S. (2009). In 2025, India to Pass China in Population, U.S. Estimates. The New York Times.

Rosecrance, R. N. (1966). Bopolarity, Multipolarity, and the Future. The Journal of Conflict Resolution, 314-27.

Ross, R. S. (1999). The Geography of the peace: East Asia in the twenty first century. International Security, 23 (4), 81-188.

Schlesinger, A. (1957). The crisis of the Old Order 1919-1933.

Schuman, M. (2013). Can China Escape the Middle-Income Trap? Times Bussiness and Money .

Schwab, K. (2012). The Global Competiveness Report 2012-2013. The World Economic Forum.

Scott, D. (2006). India's “Grand Strategy” for the Indian Ocean: Mahanian Visions. Asia-Pacific Review , 13 (2).

Scott, D. (2008). Sino-Indian Security Predicaments for the Twenty-First Century. Asean Security , 4 (3), 244-270.

Scowcroft, B. (2012). A world in Transformation. Atlantic Council .

Segal, G. (Summer, 1993). The Coming Confrontation between China and Japan? World Policy Journal , 10 (2), 27-32.

Shah, A. (2008, August 10). Global Food Crisis . Global Issues. org. Retrieved from: (http://www.globalissues.org/article/758/global-food-crisis-2008.

Shambaugh, D. (Winter 2011). Coping with a Conflicted China. The Washington Quarterly, 34 (1), 7-27.

Sieff, M. (2013). Japan aims to increase regional stability by increasing military spending. Asia Pacific Defense Forum .

Singh, P. P. (2012, December 7). Shinzo Abe's challenges in reviving Japan's economy. BBC News .

Skanderup, J. (2004). Taiwan's Cross-Strait Economic Strategy and the WTO. Pacific Forum CSIS .

Stavridis, Daalder Ivo H. and James G. (June 2012). NATO'S Victory in Libya: The right way to run an intervention. In T. C. Command, Military Review (pp. 1-89). Tirana: The Center for Defence Analyses (CDA) of the Albanian Training.

Subramanian, A. (2011, September/October). The Inevitable Superpower Why China's Dominance Is a Sure Thing. Foreign Affairs , 3-8.

Sumit Ganguly \& Manjeet S. Pardesi. (2009). Explaining Sixty Years of India's Foreign Policy. India Review , 8 (1), 4-19.

Thanh, V. H. (2013). Khủng hoảng kinh tế Mỹ và tác động của nó tới quan hệ kinh tế Việt Nam- Nhật Bản. Institute for Northeast Asian Studies .

(1946). The Atomic Bombings of Hiroshima and Nagasaki. Pennsylvania State University.

(September 2002). The National Security Strategy of the United States of America. The White House. 
(2001). The United States and Asia: Toward a New U.S. Strategy and Force Posture. RAND.

The USA and Japan intend to drill China. (2011). The Voice of Russia .

(2009). The US-China business Council. China and the US economy: advancing a winning trade agenda.

Thinh, N. T. (2012). Mỹ và Trung Quốc: Lợi ích vừa đan xen, vừa thách thức. Nghien cuu bien Dong .

Thirkell-White, B. (n.d.). External Constraints: From the Structural Impediments initiative to global imbalances.

ThuyDung. (2012). Mỹ, Trung chỉ đấu khẩu trong tranh chấp thương mại. $V n$ Express .

Tim, D., Milja, K. , Steve, S. (2009). International Relations Theories. New York, US: Oxford University press.

Tisdell, C. (2009). Economic Reform and Openness in China: China's Development Policies in the Last 30 Years. Economic analysis \& Policy, 39 (2).

Toàn cảnh thế giới, VTV1, 5.26.2013. Retrieved from: http://www.youtube.com/watch? $v=1$ J JhleyI $3 G k$

Toàn cảnh thế giới, VTV1, 6.9.2013. Retrieved from:

http://vtv.vn/video-clip/131/Talkshow/category49/Toan-canh-the-gioi09062013/video10272/page6.vtv.

Tønnesson, S. (2009). What is it that best expalains the East Asian Peace Since 1979? A call for a research agenda. Asian Perspective.

Top News Stories of the 21st Century. (2012). Global News Monitor .

Trung Quốc muốn biến Biển Đông thành ao nhà (China wants the South China sea become a home pond). (2013). LaoDong online .

Trung Quốc: Dân số già và những hệ quả tất yếu. (2007). Vietbao.vn .

U.S. military to boost Philippines presence; China tells army to be prepared. (2012). Reuters .

US rebalance to Asia-Pacific gaining steam, Pentagon chief says. (2013). Thanhniennews .

Valencia, M. J. The South China Sea: Back to the Future. Global Asia , 5 (4), Winter 2010.

Vietnam, China seek peaceful, stable solutions to sea dispute. (2013). ThanhNiennews.com .

Virmani, A. (2005, March). A Tripolar century: USA, China, and India. WORKING PAPER NO 160 , pp. 1-150.

Waksman, K. (2012). Top Countries Exporting to the U.S. About.com .

Walt, S. (1985). Alliance Formation and the Balance of World Power. International Security , 9 (4), 3-43.

Walt, S. (2011). The End of the American Era. The National Interest .

Waltz, K. N. (Summer 1964). The stability of a bipolar world. Daedalus , 93, 319342.

Waltz, K. (1979). Theory of International Politics. Reading, MA: Addision-Wesley, 1979. Quoted in Robert Ayson, Regional Stability in the Asia-Pacific. 
Waltz, K. , The spread of Nuclear Weapons: More May Be Better, Adelphi Paper No.171 (London: International Institue for Strategic studies, Autum 1981)

WeiWei, Z. (Spring 2013). Why China prefers its own political model . Europe's World .

Wen Jiabao: China Disagrees to So-called G2. (2009). China Today- Explaining China to the World.

Wen: China disagrees to so-called G2. (2009). China Daily.com.vn .

White Paper on Peaceful Development Road Published. (2010). The State Council Information Office. Retrieved from: China.org.cn Retrieved from: http://www.china.org.cn/english/2005/Dec/152669.htm.

White, H. (2012). The China Choice: Why America Should Share Power. Collingwood VIC: Black Inc.

(2012). World Economic outlook. International Monetary Fund. Retrieved from: http://www.imf.org/external/pubs/ft/weo/2012/01/index.htm.

(2013). World Economic Situation and Prospects 2013. New York: United Nations http://www.un.org/en/development/desa/policy/wesp/wesp_current/2013Chap1 _embargo.pdf.

Yang, J. (2008). Chinese Perspectives on a "Fair and Rational" International Order. Asia New Zealand Foundation, 1-7.

Yang, J. (2010). Japan's decline relative to China: Scenarios and implications for East Asia. Political Science, 62 (2), 146-165.

Zakaria, F. (2008). The Post- American World. New york: W.W. Norton.

Zhongzhou, L. (2013). Seeking a win-win scenario in trade between China, US. China Daily USA 
